OPEN ACCESS

Edited by:

Zhenhai Chen,

Yangzhou University, China

Reviewed by:

Sherry Layton,

Vetanco S.A., Argentina

Uwe Fischer,

Friedrich-Loeffler-Institute, Germany

*Correspondence:

Constantinos S. Kyriakis

csk@auburn.edu

Specialty section:

This article was submitted to

Veterinary Infectious Diseases,

a section of the journa

Frontiers in Veterinary Science

Received: 15 January 2021 Accepted: 17 March 2021

Published: 15 April 2021

Citation:

Aida V, Pliasas VC, Neasham PJ, North JF, McWhorter KL, Glover SR and Kyriakis CS (2021) Novel Vaccine Technologies in Veterinary Medicine: A Herald to Human Medicine Vaccines.

Front. Vet. Sci. 8:654289

doi: 10.3389/fvets.2021.654289

\section{Novel Vaccine Technologies in Veterinary Medicine: A Herald to Human Medicine Vaccines}

\author{
Virginia Aida ${ }^{1,2}$, Vasilis C. Pliasas ${ }^{1,2}$, Peter J. Neasham ${ }^{1,2}$, J. Fletcher North ${ }^{1,2}$, \\ Kirklin L. McWhorter ${ }^{1,3}$, Sheniqua R. Glover ${ }^{1,2}$ and Constantinos S. Kyriakis ${ }^{1,2,4 *}$ \\ ${ }^{1}$ Department of Pathobiology, College of Veterinary Medicine, Auburn University, Auburn, AL, United States, \\ ${ }^{2}$ Emory-University of Georgia (UGA) Center of Excellence for Influenza Research and Surveillance (CEIRS), Auburn, AL, \\ United States, ${ }^{3}$ Department of Chemistry, Emory University, Atlanta, GA, United States, ${ }^{4}$ Center for Vaccines and \\ Immunology, University of Georgia, Athens, GA, United States
}

The success of inactivated and live-attenuated vaccines has enhanced livestock productivity, promoted food security, and attenuated the morbidity and mortality of several human, animal, and zoonotic diseases. However, these traditional vaccine technologies are not without fault. The efficacy of inactivated vaccines can be suboptimal with particular pathogens and safety concerns arise with live-attenuated vaccines. Additionally, the rate of emerging infectious diseases continues to increase and with that the need to quickly deploy new vaccines. Unfortunately, first generation vaccines are not conducive to such urgencies. Within the last three decades, veterinary medicine has spearheaded the advancement in novel vaccine development to circumvent several of the flaws associated with classical vaccines. These third generation vaccines, including DNA, RNA and recombinant viral-vector vaccines, induce both humoral and cellular immune response, are economically manufactured, safe to use, and can be utilized to differentiate infected from vaccinated animals. The present article offers a review of commercially available novel vaccine technologies currently utilized in companion animal, food animal, and wildlife disease control.

Keywords: veterinary vaccines, new technology vaccines, food animals, companion animals, infectious diseases, disease control and prevention

\section{INTRODUCTION}

From Edward Jenner and Louis Pasteur in the eighteenth and nineteenth centuries, to the eradication of rinderpest in bovine and smallpox in the human populations by the twentieth century, vaccines have played a pivotal role in the survival, health, and general well-being of humans and animals (1-3).

The ultimate goal of vaccination is to generate humoral and/or cell-mediated immunity thereby inducing the production of immunological memory that confers protection against subsequent natural infection(s). The elicitation of neutralizing antibodies has long been the major goal of vaccines, however in addition to neutralizing antibodies, T-cell mediated immune responses have been shown to be crucial for effective protection against pathogens such as varicella virus, HIV, tuberculosis, and malaria (4-9). 
The adaptive immune response is activated primarily through the presentation of antigens bound to a Major Histocompatibility Complex (MHC) I or II on the surface of antigen presenting cells (APCs) to T-cells and B-cells within secondary lymphoid organs. However, B-cells can take up particulate and antigen without the help of APCs provided the antigen is small enough (10). MHC-I is found in all nucleated cells while MHC-II is exclusively expressed by dendritic cells, macrophages, monocytes, B-cells, and mucosal epithelial cells (11). Nonetheless, because $\mathrm{T}$ cells are unable to directly interact with antigen, the mechanism of MHC presentation in conjunction with appropriate signaling plays a pivotal role in the effector cells activated and is particularly important in vaccine development in which a T-cell mediated response is desired (12). The MHC presentation is dependent on the intracellular location of the antigen processing. Cytosol derived-antigens, such as in the case of virally infected somatic cells, are processed onto MHC-I complexes and interact with CD8+ T cells, also known as cytotoxic T cells (CTLs) which directly kill infected cells (13). APCs can also present exogenously acquired antigens on MHC-I complexes, a process termed crosspresentation (14) and upon migration to lymph nodes, will activate CTLs which will migrate out of the lymph node to eliminate infected cells.

Exogenous antigens acquired by endocytosis are presented on MHC-II molecules and interact with CD4+T helper $\left(\mathrm{T}_{\mathrm{H}}\right)$ cells. T-helper cells have various fates and effector functions which are influenced by the type of signal elicited during priming and activation. Pertinent to vaccine production, Thelper $1\left(\mathrm{~T}_{\mathrm{H}} 1\right)$ cells produce interferon- $\gamma$ and tumor necrosis factor alpha which potentiate the effector function of phagocytes and increase inflammation (15). Thus, vaccine-induced memory $\mathrm{T}_{\mathrm{H}} 1$ cells are particularly sought for intracellular pathogens. T-helper $2\left(\mathrm{~T}_{\mathrm{H}} 2\right)$ cells facilitate B-cell proliferation whilst antagonizing $\mathrm{T}_{\mathrm{H}} 1$ differentiation and are therefore associated with increased humoral responses and of particular interest for vaccines targeting parasites or allergic responses $(16,17)$. Tfollicular helper cells $\left(\mathrm{T}_{\mathrm{FH}}\right)$ interact with B-cells that present antigen on MHC-II molecules $(12,18,19)$. Only B cells that receive co-stimulatory signals from $\mathrm{T}_{\mathrm{FH}}$ cells are able to generate high-affinity IgG antibodies or mature into memory B-cells (20). As such, vaccines aimed to generate robust B-cell memory need to also stimulate $\mathrm{T}$-cell responses.

The classical inactivated and modified-live vaccines (IV and MLV, respectively), also known as first generation vaccines, have given humans and animals alike advantages over the pathogenic world that surrounds them. These vaccines have also had an economic impact due to the success that has been seen in livestock industries (21). IVs are safe and relatively inexpensive to produce, predominantly present antigens via the MHC-II pathway and mainly induce humoral immune responses. Due to this disadvantage, pathogens requiring a strong cell-mediated response can escape the pressure elicited by the vaccine (22). MLVs circumvent this issue, due to their ability to successfully replicate within the host and elicit protective immunity against their respective pathogens. These attenuated pathogens mimic natural infection thereby eliciting both MHC-I and MHC-II pathways. Some MLVs have been shown to elicit mucosal IgA antibodies, a unique feature to only a handful of vaccines administered via the oral or nasal route (23). However, MLVs pose a slight risk to animals as there were rare cases where attenuated strains regained pathogenicity, causing the spread of disease $(21,24-27)$. Additionally, MLVs are contraindicated in severely immunocompromised individuals due to the risk of disease (28). These classical vaccines have predominated commercial human and animal immunizations for the past 100 years. However, the aforementioned disadvantages have directed second and third-generation vaccines into the limelight of exploration.

These second and third generation vaccines have shown success in veterinary medicine thereby paving the way for advancement in human medicine (Figure 1). Second generation vaccines include subunit elements, conjugated/recombinant antigens, or synthetic proteins (Table 1). Recombinant subunit vaccines do not use virus (inactivated or live), but rather utilize antigen production through overexpression and purification of the antigen. This can be achieved through multiple routes, including the baculovirus expression vector system (BEVS). Subunit vaccines oftentimes lack the pathogen associated molecular patterns that the immune system utilizes to recognize pathogens via pattern recognition receptors. Because of this, subunit vaccines necessitate adjuvants with co-stimulatory activity that enhance the magnitude and quality of the immune response. Furthermore, these types of vaccines are generally recognized by antigen presenting cells via the intravesicular route and are consequently presented on MHC-II complexes.

Third generation vaccines include gene-based (DNA and RNA) vaccines, viral-vector platforms, and live or inactivated chimeric vaccines. DNA and RNA-based vaccines is a fundamentally new approach to vaccination, involving the use of plasmid DNA delivered through injection (Table 2). Advancements in molecular biology techniques have allowed us to manipulate these polynucleotides to our advantage, providing alternative routes to the classical vaccine technologies $(29,30)$. DNA vaccines employ the use of a plasmid containing the DNA encoding the antigen(s) of interest. Once inserted into host cells, the cellular machinery will express the antigens encoded by the DNA and an immune response will be elicited. Some advantages of DNA vaccines include the safe administration to immunocompromised individuals compared to MLVs, the potential for combining multiple plasmids for a broad-spectrum combination vaccine, and the ease of engineering compared to classical vaccines (31-33). Along with these advantages DNA vaccines induce both humoral and cell mediated responses, and function as pathogen associated molecular patterns (PAMPS) attenuating the necessity for adjuvant (32, 34, 35). More specifically, plasmid-DNA and RNA vaccines transfect cells and thus mimic intracellular pathogen protein production and typically induce strong MHC-I mediated CD8+T cell responses (36). Transfected somatic cells will present antigen on MHC-I, thereby eliciting CTLs cross-primed by dendritic cells. Additionally, APCs engulf transfected cells and present antigen on MHC-II complexes to elicit a CD4+ T-cell response (37).

Recombinant viral vector vaccines are novel technologies in veterinary medicine that utilize viruses as tools for vaccinology 


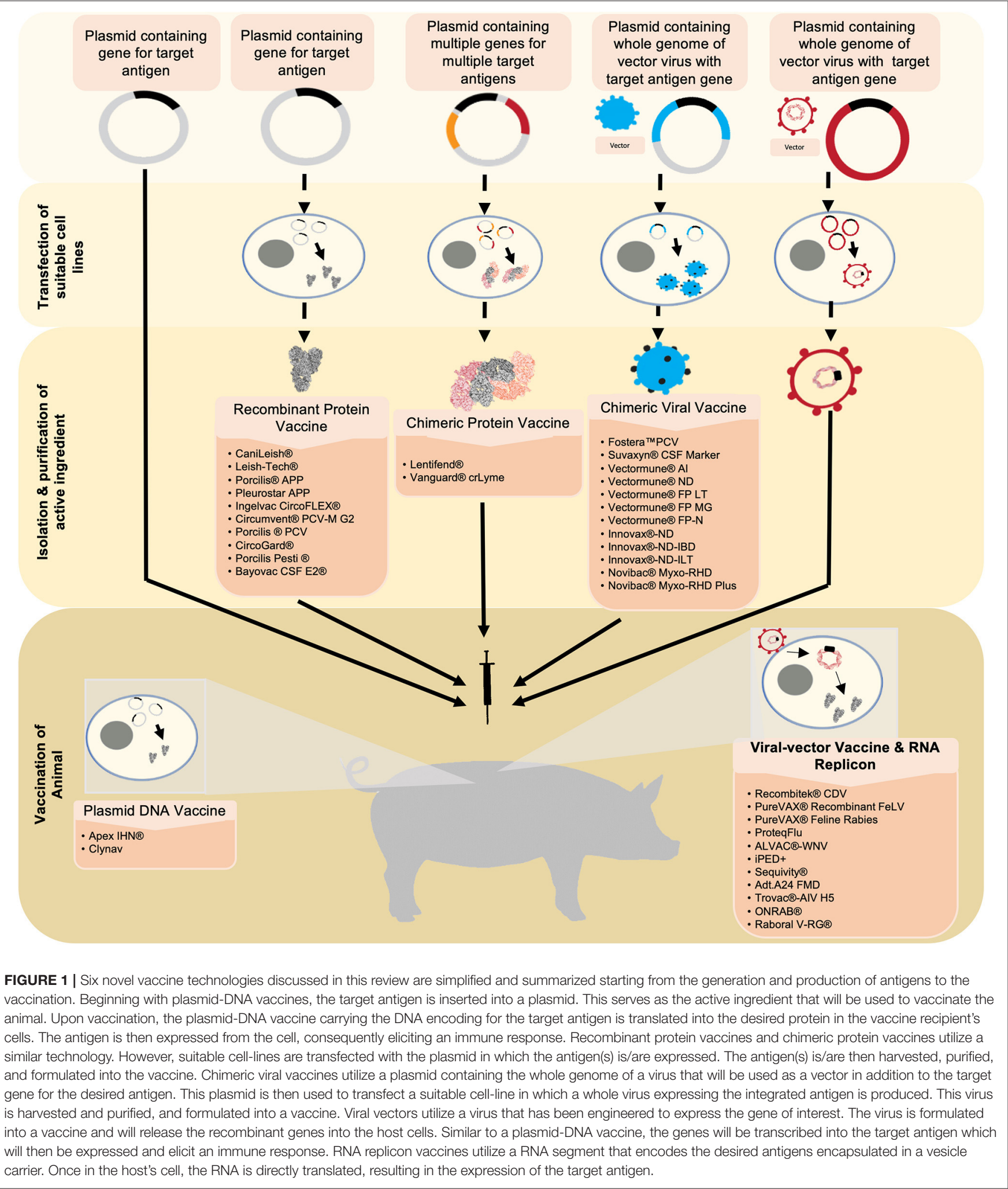

(Table 3). These vaccines are genetically engineered and involve the insertion of DNA encoding key antigens into a viral vector. The safety profile is similar to inactivated (killed) subunit vaccines and stimulate both cell-mediated, specifically CD8+T cell responses, and humoral immune responses $(9,38)$. Pox viral vectors were the first to be studied and established in 
TABLE 1 | Subunit and recombinant protein vaccines.

\begin{tabular}{|c|c|c|c|c|}
\hline Species & Vaccine & Manufacturer & Pathogen & Technology \\
\hline \multirow[t]{4}{*}{ Canine } & CaniLeish $^{\circledR}($ LiESP/QA-21) & Virbac & Leishmania & Subunit (Cell-free, serum-free culture system) \\
\hline & Leish-Tech ${ }^{\circledR}$ & CEVA Animal Health & Leishmania & Recombinant Protein \\
\hline & Lentifend ${ }^{\circledR}$ & Laboratorios Leti & Leishmania & Chimeric protein \\
\hline & Vanguard $^{\circledR}$ crLyme & Zoetis & Borrelia burgdorferi & Chimeric Protein \\
\hline \multirow[t]{8}{*}{ Swine } & Porcilis ${ }^{\circledR}$ APP & Merck Animal Health & A.pleuropneumoniae & Subunit \\
\hline & Pleurostar APP & Novartis & A.pleuropneumoniae & Subunit \\
\hline & Ingelvac CircoFLEX ${ }^{\circledR}$ & Boehringer Ingelheim & Porcine Circovirus Type 2 & Subunit (BEVS) \\
\hline & Circumvent ${ }^{\circledR}$ PCV-M G2 & Merck Animal Health & Porcine Circovirus Type 2 & Subunit (BEVS) \\
\hline & Procilis ${ }^{\circledR}$ PCV & Merck Animal Health & Porcine Circovirus Type 2 & Subunit (BEVS) \\
\hline & CircoGard & Pharmgate Animal Health & Porcine Circovirus Type 2 & Subunit (BEVS) \\
\hline & Porcilis Pesti ${ }^{\circledR}$ & Merck & Classical Swine Fever & Subunit (BEVS) \\
\hline & Bayovac CSF E2 ${ }^{\circledR}$ & Bayer & Classical Swine Fever & Subunit (BEVS) \\
\hline
\end{tabular}

TABLE 2 | DNA vaccines.

\begin{tabular}{|c|c|c|c|c|}
\hline Species & Vaccines & Manufacturer & Pathogen & Plasmid(s) \\
\hline \multirow[t]{2}{*}{ Salmonid } & Apex $\|{ }^{\circledR}$ & Elanco (Aqua Health) & Infectious Hematopoietic Necrosis & pUK21-A2, pUK-innG \\
\hline & Clynav & Elanco (Aqua Health) & Salmonid Alphavirus Subtype 3 & PUK-SPDV-poly2\#1 \\
\hline
\end{tabular}

TABLE 3 | Recombinant viral vector vaccines.

\begin{tabular}{|c|c|c|c|c|}
\hline Species & Vaccine & Manufacturer & Pathogen & Technology (viral-vector) \\
\hline Canine & Recombitek ${ }^{\circledR}$ CDV & Boehringer Ingelheim & Canine Distemper Virus & Viral-Vector (canarypox) \\
\hline \multirow[t]{2}{*}{ Feline } & PureVAX ${ }^{\circledR}$ Recombinant FeLV & Boehringer Ingelheim & Feline Leukemia Virus & Viral-Vector (canarypox) \\
\hline & PureVAX ${ }^{\circledR}$ Feline Rabies & Boehringer Ingelheim & Rabies & Viral-Vector (canarypox) \\
\hline \multirow[t]{2}{*}{ Equine } & ProteqFlu & Boehringer Ingelheim & Equine Influenza & Viral-Vector (canarypox) \\
\hline & ALVAC $^{\circledR}-W N V$ & Pfizer & West Nile Virus & Viral-Vector (canarypox) \\
\hline \multirow[t]{4}{*}{ Swine } & Fostera ${ }^{\mathrm{TM}} \mathrm{PCV}$ & Zoetis & Porcine Circovirus Type 2 & Chimeric Viral-vector (PCV-1) \\
\hline & Suvaxyn ${ }^{\circledR}$ CSF Marker & Zoetis & Classical Swine Fever virus & Chimeric Viral-vector (BVDV) \\
\hline & ¡PED+ & Merck Animal Health & Porcine Endemic Diarrhea virus & RNA Replicon (VEEV) \\
\hline & Sequivity ${ }^{\circledR}$ & Merck Animal Health & Swine influenza A virus & RNA Replicon (VEEV) \\
\hline Bovine & Adt.A24 FMD & GenVec & Foot and Mouth Disease & Viral-vector (adenovirus) \\
\hline \multirow[t]{9}{*}{ Avian } & Trovac $^{\circledR}$-AIV H5 & Boehringer Ingelheim & Avian Influenza & Viral-vector (fowlpox) \\
\hline & Vectormune $^{\circledR} \mathrm{Al}$ & CEVA Biomune & Avian Influenza & Chimeric Viral-vector (HVT/MD) \\
\hline & Vectormune ${ }^{\circledR} \mathrm{ND}$ & CEVA Biomune & Newcastle Disease & Chimeric Viral-vector (HVT/MD) \\
\hline & Vectormune ${ }^{\circledR}$ FP LT & CEVA Biomune & Infectious Laryngotracheitis virus & Chimeric Viral-vector (fowlpox) \\
\hline & Vectormune ${ }^{\circledR}$ FP MG & CEVA Biomune & Mycoplasma Gallisepticum & Chimeric Viral-vector (fowlpox) \\
\hline & Vectormune ${ }^{\circledR}$ FP-N & CEVA Biomune & Newcastle Disease & Chimeric Viral-vector (fowlpox) \\
\hline & Innovax ${ }^{\circledR}-\mathrm{ND}$ & Merck Animal Health & Newcastle Disease & Chimeric Viral-vector (HVT/MD) \\
\hline & Innovax ${ }^{\circledR}$-ND-IBD & Merck Animal Health & Newcastle disease and Infectious bursal disease & Chimeric Viral-vector (HVT/MD) \\
\hline & Innovax ${ }^{\circledR}-\mathrm{ND}-\mathrm{ILT}$ & Merck Animal Health & Newcastle disease and infectious laryngotracheitis & Chimeric Viral-vector (HVT/MD) \\
\hline \multirow[t]{2}{*}{ Wildlife } & $\mathrm{ORNAB}^{\circledR}$ & Artemis Technologies, Inc., & Rabies & Viral-vector (human adenovirus type 5) \\
\hline & Raboral V-RG ${ }^{\circledR}$ & Boehringer Ingelheim & Rabies & Viral-vector (vaccinia virus) \\
\hline \multirow[t]{2}{*}{ Rabbits } & Novibac ${ }^{\circledR}$ Myxo-RHD & Merck Animal Health & Rabbit Hemorrhagic Disease & Chimeric Viral-vector (myxoma virus) \\
\hline & Novibac ${ }^{\circledR}$ Myxo-RHD Plus & Merck Animal Health & Rabbit Hemorrhagic Disease & Chimeric Viral-vector (myxoma virus) \\
\hline
\end{tabular}

the 1980's, with various backbones being utilized to induce responses to various animal pathogens, including canarypox and fowlpox backbones (39-43). Adenovirus vectors have been explored as systems of treatments for numerous infections, and even as vaccines against tumor-associated antigens (44). Positive sense RNA-containing alphaviruses have also been used 
as vector backbones, and these constructs include two types: fulllength infectious clones and replicon vectors. The latter type is advantageous due to their lack of structural protein genes, only containing the non-structural genomic region and the genes encoding the antigen(s) of interest (45). For alphavirus-replicons, foreign genes of interest can be inserted in the place of the structural genes generating self-replicating RNA replicons (RP) (46). Upon inoculation, the RP is engulfed by dendritic cells and consequently directs the translation of large amounts of protein in the cells resulting in the presentation of the antigen. This essentially makes them self-replicating RNA molecules. These concepts can then be extended into chimeric recombinant vector vaccines, where the principles are the same, yet the genes, and by extension antigens, of interest are taken from multiple types of the pathogen and placed within the same vector, aiming to elicit a broader immune response.

Another component that distinguishes veterinary from human vaccines is the technology that enables the differentiation of infected and vaccinated animals (DIVA), making them a critical tool in disease control and eradication (47). This technology has also made a huge impact on imports and exports as it provides a sensitive, rapid, and inexpensive method for determining pathogen free flocks and herds (48). Most DIVA vaccines, or marker vaccines, are based on recombinant deletion mutants of wild-type pathogens, where gene segments expressing viral proteins, such as the herpesvirus envelope glycoprotein (gE), have been removed. Other DIVA vaccines are based on subunit vaccines and inactivated whole virus vaccines (Table 4). Because DIVA vaccines elicit a different immune response from that elicited by a natural infection companion diagnostic tests, typically an enzyme linked immunosorbent assays (ELISA) can be utilized to discern those infected and those vaccinated. DIVA vaccines have been utilized in the control of Foot-andmouth disease, Classical swine fever, Bovine rhinotracheitis, and the eradication of Pseudorabies (Aujesky's disease) in pigs (49-51).

Overall, veterinary medicine has made great strides in vaccine development for a wide array of pathogens, and has spearheaded vaccinology methodologies and designs, being years in advance compared to human vaccine technologies. In this review, current commercially available and licensed technologies being utilized in veterinary vaccinology are presented.

\section{COMPANION ANIMALS}

\section{Canine Vaccines}

\section{Canine Distemper Virus-Recombitek ${ }^{\circledR}$ Combination Vaccines (CDV)}

Canine distemper virus (CDV) belongs to the Paramyxoviridae family and is closely related to the human measles virus and bovine rinderpest virus. CDV is found worldwide, affects all members of the canidae family, and is responsible for significant disease, often resulting in high morbidity and mortality in unprotected animals. Recombitek ${ }^{\circledR}$ vaccines, produced by Merial Animal Health (now Boehringer Ingelheim Animal Health), utilize a recombinant canarypox-vector expressing both the antigenic hemagglutinin and fusion glycoproteins of CDV and are co-formulated with other MLVs (adenovirus type 2, coronavirus, parainfluenza, or parvovirus) or bacterial antigens. These vaccines are the only virus-vectored CDV vaccines licensed and commercially available for canines to-date. One of the major benefits to this vaccine is the canarypox-vector does not have the complete CDV genome nor infectious components of $\mathrm{CDV}$ and therefore the risk of post-vaccinal CDV encephalitis is eliminated (52). Studies have shown the Recombitek ${ }^{\circledR}$ CDV has comparable time-to-immunity to MLV-CDV vaccines, can confer moderate protection against virus challenge within hours of being vaccinated, and fully protects animals within 1 week of vaccination (53). Furthermore, unlike MLV-CDV vaccines, Recombitek $^{\circledR}$ CDV can be utilized in pre-weaning disease and immunosuppressed individuals as it was shown to protect puppies in the presence of maternal antibodies whilst not suppressing lymphocyte responsiveness $(54,55)$. Recombitek ${ }^{\circledR}$ CDV has a significant anamnestic response and confers a 4 -fold greater increase in titer upon booster vaccination (particularly when the dogs received a MLV-CDV vaccine initially) and a 36 months serologic duration of immunity (56-58). In comparison to MLV-CDV vaccines, Recombitek ${ }^{\circledR}$ CDV induces a lower serum-neutralizing titer compared to MLV-CDV vaccines in non-domestic carnivores (59).

\section{Canine Lyme disease-VANGUARD ${ }^{\circledR}$ crLyme}

Lyme disease, caused by the spirochete Borrelia burgdorferi, is the most common vector-borne illness in North America and Europe and infects a range of vertebrate animals including small mammals, lizards, and birds $(3,60)$. Previous studies have shown that $63 \%$ of dogs exposed to infected ticks, the vector transmitting $B$. burgdorferi, develop clinical signs of Lyme disease which consist of severe elbow or shoulder joint lameness of sudden onset, joint swelling of the shoulder, elbow and carpus, and acute arthritis (61). There are several commercially available canine vaccines against $B$. burgdorferi by inducing the production of outer surface protein A (OspA) borreliacidal antibodies. These antibodies form a membrane attack complex within the tick transmitting $B$. burgdorferi during the blood meal on the host (62). Because OspA is genospecific, it has been identified that targeting both OspA and outer surface protein $\mathrm{C}(\mathrm{OspC})$ is a more advantageous vaccination tactic because OspC is conserved among several of the pathogenic Borrelia genospecies. Nonetheless, the combination of both antigens provides complete protection from Lyme disease (6366). VANGUARD ${ }^{\circledR}$ crLyme, created by Zoetis, is the only commercially available chimeric recombinant Lyme vaccine based on chimeric epitope-based recombinant proteins. It contains both antigens for OspA and 14 different linear epitopes derived from seven types of OspC and thus provides broad-spectrum protection (67). While investigating the efficacy and safety of VANGUARD ${ }^{\circledR}$ crLyme, researchers found the vaccine showed a $93.7 \%$ reduced incidence of $B$. burgdorferi infection and demonstrated significant humoral responses to both OspA and OspC after vaccination. Upon challenge with ticks suspected of carrying B. burgdorferi, vaccinated animals showed no humoral response to OspC antigen suggesting VANGUARD ${ }^{\circledR}$ crLyme prevented $B$. burgdorferi transmission 


\begin{tabular}{llll} 
TABLE 4 | DIVA vaccines. & & & \\
\hline Species & Vaccine & Manufacturer & Pathogen \\
\hline Canine & Leish-Tech $^{\circledR}$ & CEVA Animal Health & Leishmania \\
& Lentifend $^{\circledR}$ & Laboratorios Leti & Leishmania \\
Feline & PureVAX ${ }^{\circledR}$ Recombinant FeLV & Boehringer Ingelheim & Feline Leukemia Virus \\
Swine & Porcilis ${ }^{\circledR}$ Begonia & Merck Animal Health & Suid Herpesvirus 1 \\
& Auskipra ${ }^{\circledR}$ GN & Hipra & Suid Herpesvirus 1 \\
& Suvaxyn ${ }^{\circledR}$ CSF Marker & Zoetis & Classical Swine Fever Virus \\
Bovine & Adt.A24 FMD & GenVec & Foot and Mouth Disease \\
& Bovilis ${ }^{\circledR}$ IBR Marker Live & Intervet & Bovine Herpesvirus-1 \\
& Hiprabovis ${ }^{\circledR}$ IBR Marker Live & Hipra & Bovine Herpesvirus-1 \\
& Bayovac IBR Marker Vivum & Bayer & Bovine Herpesvirus-1 \\
& Bayovac IBR Marker Inactivum & Bayer & Bovine Herpesvirus-1 \\
& Rispova ${ }^{\circledR}$ IBR-Marker Inactivated & Zoetis & Bovine Herpesvirus-1 \\
& Rispova ${ }^{\circledR}$ IBR-Marker Live & Zoetis & Bovine Herpesvirus-1 \\
\hline
\end{tabular}

from infected ticks to vaccinated dogs (68). In contrast to these findings, the comparison of VANGUARD ${ }^{\circledR}$ crLyme to Recombitek ${ }^{\circledR}$ Lyme (the commercially available monovalent recombinant OspA vaccine) revealed VANGUARD ${ }^{\circledR}$ crLyme elicited a slower anti-OspA antibody response, had a lower serum borreliacidal activity at all post-vaccination time points, and had inferior immunogenicity (69). Grosenbaugh et al. (69), note that the variation in efficacy could be contributed to the lipidation differences of the antigens but also a mismatch between the OspC antigens used in the vaccine and the antibody assay used to evaluate the response. In a more recent study, VANGUARD ${ }^{\circledR}$ crLyme was shown to induce broadly cross-reactive antibodies to 25 recombinant OspC variants screened against sera of vaccinated animals, significantly reduce histopathological changes at the tick bite site, and prevent $B$. burgdorferi-induced synovitis and dermatitis (68).

\section{Canine Visceral Leishmaniasis-CaniLeish ${ }^{\circledR}$, Leish-Tec $^{\circledR}$, Letifend ${ }^{\circledR}$}

Canine leishmaniosis (CanL), caused by the protozoan Leishmania infantum, is a severe and chronic disease transmitted by the bite of a sandfly. Currently, leishmaniasis is endemic in the Mediterranean basin, Middle East, Central Asia, and Latin America. Importantly, domestic dogs are reservoirs for human visceral leishmaniasis in many areas (70). It is estimated that $30 \%$ of dogs in endemic areas are seropositive and some will eventually become clinically ill. Unfortunately, CanL cannot be easily cured with current therapies. Accordingly, the high prevalence implores the creation of an effective vaccine that elicits a robust and long-lasting Th1-mediated response in order to prevent the development of disease after infection. There are three vaccines available on the market to date: CaniLeish ${ }^{\circledR}$ (Virbac S.A.), Leish-Tec ${ }^{\circledR}$ (CEVA animal health), and Lentifend ${ }^{\circledR}$ (Laboratorios Leti). Leishmune ${ }^{\circledR}$ (Zoetis) was removed from the market in 2018 and will therefore not be discussed in this review.

CaniLeish ${ }^{\circledR} \quad(\mathrm{LiESP} / \mathrm{QA}-21)$ was the first leishmaniasis vaccine in Europe and is indicated for the active immunization of Leishmania by providing a significant reduction in disease progression (71). Overall, CaniLeish ${ }^{\circledR}$ is a well-tolerated vaccine formulated with $L$. infantum Excreted-Secreted Protein (LiESP) antigens and a purified extract of Quillaja saponaria (QA-21) adjuvant (72). CaniLeish ${ }^{\circledR}$ has a 4 week onset of immunity characterized predominately by an IgG-2 response to ESP and a significantly strong cell-mediated Th1-dominated immune profile that remains persistent for a full year after the primary vaccination course $(71,73,74)$. In a major clinical trial, CaniLeish ${ }^{\circledR}$ provided a protection of $68.4 \%$ in vaccinated animals compared to unvaccinated controls (71). Additionally, vaccinated dogs had lower mean parasite burdens due to the facilitation of a stronger macrophageinduced intracellular parasitic reduction in conjunction with autologous lymphocytes $(73,75)$. Unfortunately, CaniLeish ${ }^{\circledR}$ does not prevent initial entry and migration of the parasites and does not produce antibodies that can be distinguished from conventional immunofluorescence antibody tests (IFAT) diagnostic testing (71).

Leish-Tec ${ }^{\circledR}$ is licensed as another second generation vaccine in Brazil. This vaccine contains recombinant protein A2 antigens of various Leishmania species and a saponin adjuvant $(76,77)$. The vaccine is tolerated similarly to CaniLeish ${ }^{\circledR}$, elicits an antiA2 IgG1 antibody, IgG2 antibody, and Th1 immune response 1 month after vaccination $(78,79)$. This vaccination induces a significant reduction in the transmission of Leishmania spp. by sandflies that feed on anti-A2 seropositive vaccinated dogs and reduces the risk of disease progression and all-cause mortality in asymptomatic infected dogs $(80,81)$. In a field trial study, mean seroconversion time and cumulative incidence of infection among immunized dogs was $\sim 18$ months and $27 \%$, respectively while unvaccinated mean seroconversion time was $\sim 9$ months and $42 \%$, respectively (79). In that same study $43 \%$ of the vaccine recipients eventually developed clinical signs rending the efficacy of Leish-Tec ${ }^{\circledR}$ questionable (79). Currently, the Brazilian government advices the culling of all seropositive dogs. Fortunately, Leish-Tec ${ }^{\circledR}$ is considered a DIVA vaccine since the humoral response induced by Leish-Tec ${ }^{\circledR}$ can be detected by 
A2-ELISA and does not create cross-reacting interference with conventional leishmaniosis serological diagnostic tests $(79,82)$.

Lentifend ${ }^{\circledR}$ contains the recombinant antigen Protein $Q$, a chimeric protein formed by the fusion of five antigenic determinants from four Leishmania proteins and is without adjuvant (76). Lentifend ${ }^{\circledR}$ consistently elicits a cellular and humoral immune response characterized by a significant increase in complement system proteins and an early and statistically significant increase of IgG2 antibodies against Protein Q 2 weeks after vaccination $(76,83,84)$. Lentifend ${ }^{\circledR}$ has shown to be very well-tolerated, reduce circulating immune complexes, parasite burden, the incidence of clinical signs, and the number of confirmed cases, and have an overall efficacy of $72 \%$ $(76,83)$. Much like Leish-Tec ${ }^{\circledR}$, Lentifend ${ }^{\circledR}$ falls into the DIVA category $(85,86)$.

\section{Feline Vaccines}

Feline Leukemia Virus- PureVAX ${ }^{\circledR}$ Recombinant FeLV

Feline leukemia virus is an immunosuppressive retrovirus infecting domestic and wild felids. It can be transmitted via direct contact or through virus shed in saliva or nasal secretions and affects multiple organ systems. It is estimated that 2.3-3.4\% of all cats in North America are affected (87). PureVAX ${ }^{\circledR}$ Recombinant FeLV, produced by Boehringer Ingelheim Animal Health, is a non-adjuvanted canarypox virusvectored vaccine that contains the mutated envelope, gag, and truncated polymerase protein of the FeLV subtype A/Glasgow1 strain $(88,89)$. The immune response elicited by PureVAX ${ }^{\circledR}$ Recombinant FeLV is characterized by the activation of cellmediated immunity by inducing FeLV-specific $\mathrm{T}$ cell response (89-91). Compared to other commercially available vaccines, Recombinant FeLV has similar degrees of protection from persistent viremia and integration of proviral DNA upon virus challenge and a 93\% preventive fraction (92). Nonetheless, a 3year duration of immunity after a prime and boost vaccination protocol has been shown to confer full protection against persistent viremia (93).

\section{Feline Rabies-PureVAX ${ }^{\circledR}$ Feline Rabies}

Rabies is a zoonotic, progressive neurological, and fatal infection caused by rabies virus. Rabies infection is present throughout the world, responsible for over 60,000 human deaths per year, and affects all warm-blooded animals (94). PUREVAX ${ }^{\circledR}$ Feline Rabies contains the recombinant canarypox virus (vCP65) that expresses the rabies glycoprotein gene. Inoculation of animals with vCP65 demonstrated an appropriate level of foreign gene product expression sufficient enough to induce rabiesspecific serum neutralizing antibodies and $\mathrm{T}$-cell responses to protect against lethal rabies virus challenge for up to 3 years (95). PUREVAX ${ }^{\circledR}$ Feline Rabies provides full protection even when co-administered with other feline vaccines illustrating the usefulness in yearly core vaccinations (96). Additionally, because this vaccine lacks an adjuvant, there is excellent local safety and minimal inflammatory reactions since chronic inflammation at the injection site is a risk factor for vaccineinduced fibrosarcomas in felines (97).

\section{Equine Vaccines}

\section{Equine Influenza-ProteqFlu}

Equine Influenza virus (EIV) is an Orthomyxovirus considered to be an important respiratory disease in horses. Equine Influenza has had major economic and welfare implications within the last decade and is particularly difficult to control due to the virus' inclination to readily undergo antigenic drift and shift. Unfortunately, Vaccine mismatch to the circulating strain can contribute to a significantly decreased efficacy in eliciting appropriate host immune response.

ProtequFlu (marketed by Boehringer Ingelheim, formerly Merial Animal Health) contains two modified live canarypox virus recombinants expressing the EIV hemagglutinin (HA) gene of two significantly important strains of circulating EIVs.ProtequFlu has been shown to generate significantly high IgGa and IgGb anti-influenza antibody titers pre-challenge, a long-term 6-month anamnestic IgGa and IgGb protective responses post challenge with several American lineages and induces a specific IFN-y and IL-2 mRNA expression $(98,99)$. In animals older than 8 months, vaccination has shown to provide protection after a single dose compared to the required two doses of inactivated vaccine and has thus been utilized as a means for emergency response to IEV outbreaks $(100,101)$. However, some studies found that foals $<8$ months did not seroconvert until the third immunization suggesting the presence of maternally derived antibodies contributes to this immunization pattern and might influence vaccination protocols (102). Regarding longterm immunity, ProteqFlu-Te ${ }^{\circledR}$ was not as robust as the whole commercial inactivated vaccines, Equilis Prequenza-Te ${ }^{\circledR}$ and Duvaxyn IE-T Plus ${ }^{\circledR}$, or when ProteqFlu-Te ${ }^{\circledR}$ was combined in a mixed-vaccination protocol which is a common practice in the field (103).

\section{West Nile Virus-ALVAC ${ }^{\circledR}-$ WNV \& West Nile-Innovator ${ }^{\circledR}$ DNA}

West Nile Virus (WNV) is a mosquito-transmitted neurotropic Flavivirus causing debilitating and potentially fatal disease found worldwide in birds, humans and horses (the two latter species being the dead-end hosts) $(104,105)$. Successful vaccination requires both the induction of neutralizing antibodies and cellmediated immune response including the elicitation of INF- $\alpha$, INF- $\beta$, and significant involvement of the complement system $(104,106,107)$. IgM is critically important for the control of acute and early WNV infection followed by the presence of IgG antibodies which confer long-term protection against WNV re-infection $(108,109)$.

Merial Animal Health (now Boehringer Ingelheim Animal Health) developed ALVAC ${ }^{\circledR}-W N V$, a canarypox-vectored recombinant chimeric vaccine that expresses the precursor membrane (prM) and envelope (E) genes of WNV derived from the 1999 New York Isolates (110). ALVAC ${ }^{\circledR}$-WNV induces neutralizing antibodies and $\mathrm{prM} / \mathrm{E}$-insert-specific IFN-y+ producing cells against WNV in vaccinated horses and therefore plays a major role in anti-viral clearance $(107,111)$. ALVAC ${ }^{\circledR}$. WNV vaccine was shown to be fully protective against virulent WNV challenge via mosquito exposure making it exceptionally applicable in the field (112). Additionally, ALVAC ${ }^{\circledR}-\mathrm{WNV}$ 
induces WNV antibodies as early as 7 days, develop protection against viremia as early as 26 days after a single dose, was fully protective against challenge, and elicited an immune response that could be recalled 9 months after appropriate primary vaccination and booster vaccination (107, 112, 113). West Nile-Innovator ${ }^{\circledR}$ DNA, a WNV DNA plasmid-based vaccine, licensed in 2005 by Fort Dodge Animal Health/Pfitzer, contained an unformulated plasmid DNA encoding the prM and E protein of WNV and a MetaStim ${ }^{\mathrm{TM}}$ adjuvant $(110,114)$. This vaccine resulted in a humoral and strong Th1 response however, the vaccine was discontinued by Pfizer $(110,115,116)$.

\section{FOOD ANIMALS}

\section{Porcine Vaccines}

\section{Pleuropneumonia-Porcilis ${ }^{\circledR}$ APP and PleuroStar APP}

A second generation of subunit vaccines targeting the bacterium Actinobacillus pleuropneumoniae (APP) was previously developed by Merck Animal Health and Novartis. APP is the active agent that causes porcine contagious pleuropneumonia disease in swine through the bacterium's ApxI, ApxII, ApxII, and ApxIV toxins (117, 118). Fifteen known serotypes of APP are currently characterized, each that can cause variable pathogenicity (119). The acute form of porcine contagious pleuropneumonia is often fatal by inducing hemolytic and cytotoxic lung damage leading to pleuropneumonia (119). The disease is most severe in piglets 6-22 weeks old, usually before they go to market (119). Consequently, APP is a huge economic burden for the swine industry. Porcilis ${ }^{\circledR}$ APP and PleurostarAPP are commercially available second-generation subunit vaccines that each provides some cross protection against the 15 serotypes of A. pleuropneumonia (120-122). The vaccines are based on four or five purified proteins produced by $c$ strains. This includes the exotoxins ApxI, ApxII, ApxIII and a 42 kilodalton outer membrane protein for the development of PorcilisAPP, and the ApxII, TbpB, CysL, OmlA, and OmlA proteins for PleurostarAPP $(119,123)$.

Porcilis ${ }^{\circledR}$ APP has been shown to develop a protective immunity with a peak 2-3 weeks after boost vaccination which can be maintained for up to seven weeks, confer protection in terms of clinical signs, reduced lung lesions, and reduce mortality for serovar 1 (123). In an experiment conducted by Del Pozo Sacristan et al., Porcilis ${ }^{\circledR}$ APP was evaluated in herds chronically affected by pleurisy. Vaccinated animals had significantly lower prevalence and extent of pleurisy 4.1 and $2.5 \%$, respectively vs. the non-vaccinated animals of 18.5 and $8.0 \%$, respectively. Vaccinated animals gained more weight than pigs in the nonvaccinated group. Additionally, antimicrobial use and mortality were reduced in vaccinated animals suggesting that although vaccination may not prevent clinical expression of APP infection, it could be useful in reducing the impact of infection $(121,123)$.

\section{Porcine Circovirus Type 2-Ingelvac CircoFLEX ${ }^{\circledR}$, Circumvent ${ }^{\circledR}$ PCV-M G2, Porcilis ${ }^{\circledR}$ PCV, CircoGard \& Fostera $^{\mathrm{TM}}$ PCV}

Two types of circoviruses have been identified in swine, porcine circovirus 1 (PCV1) and porcine circovirus 2 (PCV2), where only the latter is considered pathogenic (124). PCV2 is the causative agent of Porcine Circovirus Associated Disease, which includes multiple clinical syndromes of swine such as Postweaning Multisystemic Wasting Syndrome, porcine dermatitis and nephropathy syndrome, and PCV2-induced reproductive disorders (125-127).

Ingelvac CircoFLEX ${ }^{\circledR}$ (produced by Boehringer Ingelheim ${ }^{\circledR}$ ), Circumvent ${ }^{\circledR}$ PCV-M G2 \& and Porcilis ${ }^{\circledR}$ PCV (both produced by Merck), and CircoGard (produced by Pharmgate Biologics) are licensed subunit vaccines that were developed using a BEVS system to express the PCV-2 ORF-2 protein (128). For both Ingelvac CircoFLEX ${ }^{\circledR}$ and Circumvent ${ }^{\circledR}$ PCV-M G2 vaccines, the ORF-2 protein is used as a basis to elicit an immune response in swine against PCV-2 (129). In general, vaccination with these technologies in young piglets resulted in attenuated weight loss, shortened viremia, and lower viral load (130). Fostera ${ }^{\mathrm{TM}}$ PCV vaccine produced by Zoetis is single-dose inactivated chimeric PCV1-2 viral-vector vaccine. It utilizes the genome of the nonpathogenic PCV1 as the backbone, cloned with the ORF2 gene of PCV2 which encodes the immunogenic capsid protein of the virus (131). Vaccinated animals demonstrated increased concentration of neutralizing antibodies and anti-PCV2 IgG antibody titers which correlate with the significant reduction of viremia and replication of PCV2 compared to negative control animals $(132,133)$. Moreover, this chimeric vaccine induced a strong cell mediated immune response (CD3+ and CD4+ cells) that may explain the decrease of PCV2 genomic copies in the blood of immunized pigs (132).

\section{Suid Herpesvirus-1 (Pseudorabies/Aujesky's Disease)-Porcilis ${ }^{\circledR}$ Begonia (MSD Animal Health- Intervet), Auskipra ${ }^{\circledR}$ GN (Hipra)}

Suid herpesvirus 1 (SuHV-1) is an Alphaherpesvirus responsible for Aujesky's disease (also known as Pseudorabies). This highly contagious pathogen infects a wide range of animal species with swine being the principal reservoir and host of the virus. Disease in pigs includes a variety of clinical symptoms, neurological signs and high mortality rate up to $100 \%$ in piglets while older pigs mainly showcase respiratory signs. Infected sows demonstrate a variety of reproductive disorders such as abnormal return to estrus, abortions, stillbirth, mummified or week piglets (50). The predominant clinical symptoms in secondary hosts (cattle, dogs, and cats) are severe pruritus and neurological disorders (127). Nonetheless, this pathogen causes significant economic losses in naïve pig farm production sites and still remains a notifiable disease in the USA (134). SuHV-1 is a DNA virus comprised of several genes that contribute to the pathogen virulence but are not essential for viral replication while the tk and gE genes have been the primary target for deletion to achieve inactivation of the virus.

Porcilis ${ }^{\circledR}$ Begonia (MSD Animal Health- Intervet) is a tk and $\mathrm{gE}$ deletion mutant live attenuated vaccine. It is being used for the prevention of clinical symptoms and mortality by Aujesky's disease. This vaccine has been developed to protectively immunize the animals for a period of 4 months (135, 136). Auskipra ${ }^{\circledR}$ GN (Hipra) is a live attenuated gE negative Bartha K61 strain vaccine and has shown to prevent 
clinical symptoms and reduce viral shedding of Chinese SuHV1 variants (AH02 strain) $(137,138)$. Both of the vaccines can been used in vaccination programs to control and eradicate pseudorabies $(139,140)$.

\section{Pestivirus - Suvaxyn ${ }^{\circledR}$ CSF Marker, Porcilis ${ }^{\circledR}$ Pesti, and Bayovac CSF E2 ${ }^{\circledR}$}

Classical swine fever (CSF), is caused by a pestivirus of the family Flaviviridae (127). CSF virus (CSFV) is a small, enveloped virus with a single-stranded positive sense RNA genome which encodes a polyprotein, post-translationally cleaved to 12 final products, including the E2 structural glycoprotein that has a critical role in viral replication $(141,142)$. The eradication of CSF in several countries in Western Europe, North America and Australia is by in large credited to the Chinese lapinized vaccine (C-strain), an attenuated strain of CSF, developed by China Institute of Veterinary Drugs Control and Harbin Veterinary Research Institute in 1956 (143). However, this highly contagious viral disease remains of worldwide significance with a high mortality rate. CSFV is still endemic in many parts of the world, including most of Asia, Central and South America and multiple countries in Eastern Europe, resulting to sporadic outbreaks in highly susceptible naïve swine populations in neighboring CSF free countries $(127,144)$.

Pigs are typically infected with CSFV by the oronasal route, by contact of susceptible swine with infected feral or domestic pigs, or ingestion of uncooked swill, with tonsil as the initial site of viral replication. Animals in the acute form of disease, are exhibiting high fever, loss of appetite, depression, and conjunctivitis frequently succeeded by diarrhea, vomiting, cutaneous erythema and central nervous system clinical signs, days or weeks before they eventually die. Additionally, CSFV is able to cross the placenta and transmit to the fetuses resulting to mummifications, abortion, stillbirths or fetal deformities (127, 144, 145).

A promising commercially available vaccine is Suvaxyn ${ }^{\circledR}$ CSF Marker, the CP7_E2_alf chimeric vaccine which is licensed by the European Medicines Agency. The vaccine utilizes a live-attenuated bovine viral diarrhea virus (BVDV) backbone a expressing the E2 glycoprotein of CSFV (146). This is an effective strategy as the E2 glycoprotein is the major neutralizing antigen of CSFV $(147,148)$. In addition, the design of the CP7_E2_alf vaccine enables the serological differentiation between wild-type infected and vaccinated swine in herds $(149,150)$. Intramuscular (IM) and oral vaccination has been shown to confer full protection against challenge with the highly virulent CSFV strain "Eystrup" 28 days after immunization $(146,149)$. Challenging vaccinated animals within 2 days after immunization conferred partial protection (151). Additionally, duration of immunity has been shown to last at least 6 months after one vaccination dose (152).

Porcilis Pesti ${ }^{\circledR}$ (Merck) and Bayovac CSF E2 ${ }^{\circledR}$ (Beyer AG) are licensed subunit vaccines developed using the BEVS system to express the E2 protein (153). Porcilis Pesti ${ }^{\circledR}$ has shown to be very efficacious against the low virulent strain "Glentorf" in pregnant sows, as no virus was detectable following a vaccination-challenge study and nine out of 10 litters of the vaccinated sows were protected from CSFV infection when challenged 126 days from vaccination and on day 65 of gestation (154). In a large-scale laboratory trail, both Porcilis Pesti ${ }^{\circledR}$ and Bayovac CSF E2 ${ }^{\circledR}$, were evaluated. The data revealed animals vaccinated with Bayovac CSF E2 ${ }^{\circledR}$ were better protected against clinical CSF than those that received Porcilis Pesti ${ }^{\circledR}$ as the antibody response was more pronounced and the transmission probability was reduced significantly after the second dose. When sows were challenged with virulent CSF 14 days after vaccination (day 60 of gestation) with Bayovac CSF E2 ${ }^{\circledR}$ and Porcilis Pesti ${ }^{\circledR}$, 75 and $100 \%$ of the sows had viremic piglets, respectively (155). This data collectively suggests that these vaccines have reduced efficacy during an emergency field outbreak situation in which animals had not been vaccinated at least 3 weeks prior to exposure.

\section{Porcine Endemic Diarrhea Virus -iPED+ Vaccine}

Porcine Epidemic Diarrhea virus (PEDv) is a highly contagious swine coronavirus causing enteritis in all age groups with a variable virulence and mortality depending in the strain $(156,157)$. PEDv is an enteropathogenic coronavirus comprised of a positive sensed RNA genome that encodes a spike (S) glycoprotein located on the outer surface envelope of the virus particle. The spike (S) protein of PEDv is crucial for the virus interaction with host cell receptors and was characterized to contain many epitopes recognized by the host's immune system to incite neutralizing antibodies (158-160).

iPED+ vaccine (updated to iPED RNA) was the first Alphavirus-derived replicon RNA particle vaccine licensed to control PEDv. The vaccine employs a replicon vector system which utilizes a defective Venezuelan equine encephalitis virus (VEEV) like particle to deliver and propagate the PEDv S glycoprotein antigen in swine $(161,162)$. The iPED RNA vaccine was shown to elicit PEDv-neutralizing antibodies in dams and passively acquired PEDv-neutralizing antibodies in suckling piglets, induced clinically protective immunity and reduced viral shedding in challenged pigs, and reduced farrowing mortality in challenged sows $(161,163,164)$.

\section{Swine Influenza a Virus- SEQUIVITY ${ }^{\circledR}$}

Swine influenza A virus (swIAV) is a major respiratory pathogen in pigs resulting in delayed growth, prolonged finishing time, and consequential economic damage (165-168). Sequivity is a 3rd generation vaccine technology that employs the Sequivity ${ }^{\mathrm{TM}}$ RNA Particle Technology, an alphavirus replicon vector system derived from the attenuated TC-83 strain of $\operatorname{VEEV~}(45,169,170)$. This vaccine has not been shown to be efficacious when given in the presence of maternal antibodies but does induce a strong humoral and cell-mediated immune response in animals without maternal antibodies (45, 171-173). Additionally, this vaccine platform allows the option for "Veterinary Prescription" or customized vaccines, similar to autogenous vaccines, in which individualized, single or multivalent formulations can be produced on a caseby-case basis. Accordingly, an immunogenicity and efficacy trial evaluating an $\mathrm{H} 3 \mathrm{RP}$ vaccine showed this vaccine platform elicited protective serologic response within 3 weeks 
of receiving the boost vaccination, induced a specific IFN- $\gamma$ response, prevented detectable nasal shedding and live virus within broncho-alveolar lavage fluid, and attenuated clinical disease (173).

\section{Bovine Vaccines}

\section{Foot and Mouth Disease-Adt.A24 FMD vaccine}

Foot-and-mouth disease (FMD) is caused by a highly contagious Aphthovirus that transmits between cloven-hoofed ungulates. The virus is a member of the Picornaviridae family and can be transmitted through aerosol droplets, direct contact and/or from ingestion by susceptible animals. On average 11 billion dollars (USD) is lost per annum in countries where FMD is prevalent (174). The devastating global economic impact of FMD has fast-tracked the research into FMD vaccines using novel technologies. Of interest, includes the Adt.A24 FMD vaccine, which was granted conditional licensure by the United States Department of Agriculture (USDA) to protect cattle in 2012 (175). The replication deficient Adt.A24 vaccine utilizes a human adenovirus construct as a vector to deliver empty capsids of the A24 FMD strain to elicit an immune response (175). Previous studies in bovine and swine has shown that the Adt.A24 vaccine prevents FMD, along with FMD viremia 7-days after initial vaccination and is most efficacious when combined with the ENABL ${ }^{\circledR}$ adjuvant $(176,177)$. This vaccine has no reversion to virulence, no shedding from vaccines to naïve animals, no excretion in milk from lactating dairy cattle and conferred $64 \%$ efficacy against clinical FMD $(178,179)$. Lastly, the Adt.A24 vaccine enables the use of a DIVA strategy for evaluating herds during an outbreak.

Bovine Herpesvirus Type 1 - Bovilis ${ }^{\circledR}$ IBR Marker Live, Hiprabovis ${ }^{\circledR}$ IBR Marker Live, Bayovac IBR Marker Vivum, Bayovac IBR Marker Inactivatum, Rispoval ${ }^{\circledR}$ IBR-Marker Inactivated, Rispoval ${ }^{\circledR}$ IBR-Marker Live

Cattle infected with Bovine Herpesvirus 1 (BoHV-1) are at risk of developing Infectious Bovine Rhinotracheitis (IBR), an acute and highly contagious disease affecting the upper respiratory tract (180). Additionally, BoHV-1 infection can also impact fertility, reproduction, and productivity. Bovilis ${ }^{\circledR}$ IBR Marker Live, Hiprabovis ${ }^{\circledR}$ IBR Marker Live, Bayovac IBR Marker Vivum, Bayovac IBR Marker Inactivatum, Rispoval ${ }^{\circledR}$ IBR-Marker inactivated, and Rispoval ${ }^{\circledR}$ IBR-Marker live are licensed vaccines for use in cattle against BoHV-1. All of these IBR vaccines have the gE- deletion; the Hipravovis ${ }^{\circledR}$ IBR Marker live also has the tk- deletion. A disadvantage to utilizing some of these modified-live gE-product is the potential for latency in immunized animals and consequent reactivation or shedding following a provoked immunosuppressive state $(181,182)$. It has been shown that inactivated gE-deleted vaccines reduced viral excretion more efficiently than live gE-deleted vaccines in latently infected animals induced into an immunosuppressive state (183). Nonetheless, these marker vaccines administered either IM or IN induce a robust humoral and cell-mediated immune response making them versatile and valuable (184). Bovilis IBR Marker Live has been shown to prohibit nasal secretion shedding, prevent viremia, to elicit a humoral immune response in pregnant cattle until at least 180 days post calving, and provide passive immunity to calves until at least 180 days post calving $(185,186)$.

\section{Poultry Vaccines}

\section{Avian Influenzas-Trovac ${ }^{\circledR}$-AIV H5, Vectormune ${ }^{\circledR}$ Al}

Avian Influenza Viruses (AIV), are important pathogens for both poultry production and for human health. AIVs are enveloped, negative sense single stranded RNA viruses of the Orthomyxoviridae family and are classified as either highly pathogenic or low pathogenicity in avian species. Trovac ${ }^{\circledR}$. AIV H5 (TROVAC-H5), produced by Boehringer-Ingelheim, contains a live recombinant fowl pox-vectored backbone that expresses an $\mathrm{H} 5 \mathrm{HA}$ subtype isolate synthetically generated based on a highly pathogenic AIV HA protein and altered to mimic a low pathogenicity virus. When a single dose was administered to 1-day old chicks, duration of immunity lasted at least 20 weeks providing significant and rapid protection especially within field conditions $(187,188)$. Importantly, this vaccine was not efficacious against animals pre-immunized against or infected with fowlpox as protection against AIV levels decreased (189).

Vectormune ${ }^{\circledR}$ AI from CEVA Animal Health, uses a similar synthetic avian IAV HA protein inserted into a turkey herpesvirus (HVT) backbone. Vaccination conferred robust and long-lasting protection in commercial flocks, prevented the development of clinical disease, and suppressed shedding of high-pathogenicity avian influenza $(190,191)$.

\section{Newcastle Disease-Innovax ${ }^{\circledR}$-ND, Vectormune ${ }^{\circledR}$ FP-ND}

Newcastle Disease (ND) is a viral disease of domestic poultry, including chickens, turkeys, pigeons, pheasants, ducks and geese, of a worldwide importance (192). The infectious agent, Newcastle Disease Virus (NDV) or avian paramyxovirus serotype 1 , is a highly contagious, negative sense single stranded RNA, virus of the Paramyxoviridae family. Transmission of NDV can occur by inhalation or by ingestion of contaminated feed or water, via the discharges and droppings of infected birds, and can spread rapidly through the flock. Like AIV, NDV can be further classified on the basis of its virulence, as velogenic (highly pathogenic), mesogenic (moderate pathogenicity), or lentogenic (subclinical or avirulent). Velogenic strains cause acute respiratory disease accompanied by nervous signs and high mortality that in susceptible flocks can approach to $100 \%(193,194)$.

ND has seen advancements in commercial vaccine technologies similar to AIV. Innovax-ND, from Merck, inserts the Fusion (F) protein, a strongly immunogenic antigen, gene from NDV into an HVT vector. As with any HVT vector, vaccinated animals developed strong immunity against $\mathrm{MD}$, but importantly developed protection against lethal challenge with NDV (195). A more recent and novel development in ND vaccines is Vectormune ${ }^{\circledR}$ FP-ND from Ceva which also utilizes a viral vector, however in this case it is Fowl pox. 


\section{Infectious Bursal Disease, Mareks, Disease and Infectious Laryngotracheitis-Innovax ${ }^{\circledR}$ ND-IBD, Innovax ${ }^{\circledR}$ ND-ILT}

Infectious Bursal Disease (IBD) is caused by a double stranded DNA virus (IBDv) from the Birnaviridae family. IBD is a highly infectious disease of young domestic chickens and turkeys, characterized by immunosuppression and bursal atrophy due to depletion of B-lymphocytes. While in most cases, IBDrelated morbidity is high and mortality is low, certain highly virulent strains can cause up to $60 \%$ mortality $(196,197)$. While IBDv targets B-lymphocytes, Marek's disease (MD) virus (MDV), also called alphaherpesvirus 2 or gallid herpesvirus 2, primarily preys on $\mathrm{CD}^{+}{ }^{+} \mathrm{T}$ - lymphocytes. MDV is a highly oncogenic lymphotropic virus with worldwide distribution causing lymphoproliferative disease in chickens. Marek's disease is characterized by paralysis due to widespread presence of T-cell lymphomas localized in peripheral nerves, and visceral organs (198). Another important herpesviral disease of poultry is Infectious Laryngotracheitis (ILT), which is caused by the avian Alphaherpesvirus 1 or gallid herpesvirus 1. ILT virus (ILTv) is a double stranded DNA virus transmitted to birds through aerosols and fomites. ILT is an upper respiratory track disease causing significant economic losses due to high mortality rate (up to 70\%) (199).

The traditional method for immunization against $\mathrm{MD}$ is via a turkey herpesvirus-vectored live vaccine, since HVT is subclinical in poultry, and provides strongly crossreactive antibodies against MD. This style of multi-protective recombinant vaccines has been popularized, as Merck has produced multiple variants based on this technology. Innovax ${ }^{\circledR}$ ND-IBD uses the HVT-vector, modified to include the F gene from NDV and the VP2 surface glycorptein gene from IBDv. When challenged, animals exhibited protection against NDV, IBDV, and of course MDV for up to 60 weeks (200). Another example is Innovax ${ }^{\circledR} \mathrm{ND}$-ILT, which provides protection against NDV and ILTV. This recombinant FPV has been edited to include the $\mathrm{F}$ gene and $\mathrm{HN}$ gene from NDV, as well as the $\mathrm{gB}$ gene from ILTV. The HN construct from NDV encodes the hemagglutinin/neuraminidase proteins, while the gB gene from ILTV encodes the primary surface glycoprotein antigen. Results from vaccine trials showed roughly $70 \%$ protection against ILTV, comparable to the traditional inactivated vaccine, in addition to neutralizing immunity against NDV (201).

\section{AQUACULTURE}

\section{Salmonid Vaccines}

\section{Infectious Hematopoietic Necrosis-Apex IHN}

In the aquaculture industry, DNA vaccines have seen more success than other fields and continue to be a major field of development (202). As stated previously, DNA vaccines themselves are immunogenic and function as PAMPS and thus eliminate the need for adjuvants (203). One of the major advantages to this technology in fish is the avoidance of adjuvants which have historically been shown to cause severe reactions, such as peritonitis and melanisation of the muscle tissue in fish $(204,205)$. Apex IHN from Novartis (now Elanco
Animal Health) was developed to vaccinate against Infectious Hematopoietic Necrosis Virus (IHNV), a Rhabdovirus that causes extensive necrosis of hematopoietic tissue in early life stages and has a high mortality among Salmonids (206). This disease can affect both wild and farmed salmonids resulting in major economic loss. Apex IHN is a DNA vaccine encoding the glycoprotein $(G)$, a major antigen for protective antibodies. Given IM, this vaccine induces both innate and adaptive immune responses in fish and has conferred significant protection in Atlantic salmon, Pacific salmon, and rainbow trout (207213). Apex IHN vaccination confers a significantly attenuated mortality rate $-<3 \%$ in vaccinated animals and $99 \%$ in control animals-reduces viral spread among cohabitating naïve Atlantic salmon with infected Atlantic salmon, abolishes disease transmission amongst infected Atlantic salmon cohabitating with naïve sockeye salmon, and induces a long-lasting neutralizing antibody titer (214).

\section{Pancreas Disease - Clynav}

Clynav, produced by Elanco Animal Health, is another recombinant DNA vaccine containing the puK-SPDV-poly2\#1 plasmid and codes for several proteins from the salmonid alphavirus subtype 3 . This vaccine has been approved in the EU and Norway and is indicated to protect against pancreas disease. This disease has a significant economic burden due to the mortality, reduced growth rates, and reduced meat quality at time of slaughter (215). Fortunately, Clynav protects against weight loss, reduces the prevalence and severity of morphological tissue lesions within the cardia, pancreas and skeletal muscle, and reduces mortality for up to 1 year after vaccination. Additionally, when compared to a traditional monovalent vaccine, Clynav provided significantly higher neutralizing antibody titers, conferred lower viremia, reduced transmission to cohabitating naïve fish, and conferred a significantly higher weight gain post challenge (216). The major criticism of these DNA vaccines is the incorporation rate in the vaccinated subjects. While the incorporation rate is negligible, however it has not been precisely estimated according to manufacturers but modeled on scenarios estimating integration (217).

\section{EXOTIC ANIMALS}

\section{Wildlife}

\section{Rabies-ONRAB ${ }^{\circledR}$, RaboralV-RG ${ }^{\circledR}$}

During the last 50 years there has been a significant effort to eradicate rabies virus from domesticated companion animals by establishing mandatory vaccination programs. Currently the attention has been focused on wildlife species that are critical for the prevalence of this fatal disease and transmission to humans. According to the annual Center for Disease Control and Prevention (CDC) report about Rabies surveillance in the United States during 2017, 91\% of rabid cases involved feral animals mainly bats, raccoons, skunks and foxes (218). This highlights the importance of the development of different vaccine constructs to control and even eliminate the transmission of rabies by immunizing the most susceptible principal reservoir wildlife species. United States, Canada, and Europe have 
established an Oral Rabies Vaccination (ORV) program, to prevent the spread of rabies to raccoons, foxes, coyotes, wolves and other species that can serve as reservoirs for rabies.

Two types of recombinant vaccines that express the rabies glycoprotein have been used in oral baits to prevent this zoonotic disease. Onrab ${ }^{\circledR}$ by Artemis Technologies Inc. (Guelph, Ontario, Canada) employs a human adenovirus type 5 (Had5) vectored vaccine. Raboral V-RG ${ }^{\circledR}$ utilizes a vaccinia virus as the backbone. ORV baits are produced by Merial Ltd (Athens, GA) and consist of an edible packet that contains the Raboral V-RG ${ }^{\circledR}$. Administration of this vaccine has led to the eradication of the zoonotic rhabdovirus from 3 European countries (219). This is due to the higher efficacy of the vaccine in red foxes, which are the principal reservoir species in the continent $(220,221)$. The main objective of this vaccination program is to confer a neutralizing positive titer over $0.05 \mathrm{IU} / \mathrm{ml}$ to the targeted animals. All of the vaccinated foxes, $56 \%$ of coyotes and $62 \%$ of gray foxes have shown protective serum titers after the administration of the ORV baits (220-222). However, other mesocarnivore animals like raccoons and skunks, which are considered the primary carriers of rabies in the USA have demonstrated variable effectiveness on their immunization using ORV baits (223-225). It has been shown that Onrab ${ }^{\circledR}$ vaccine induces better protection on raccoons by inducing humoral response on $74-77 \%$ of the animals, instead of the $30 \%$ seropositivity achieved after the administration of the ORV baits $(226,227)$.

\section{Lagomorphs}

\section{Rabbit Hemorrhagic Disease - Novibac Myxo-RHD \& Novibac Myxo-RHD Plus}

The etiological agent of Rabbit hemorrhagic disease (RHD) is a highly virulent Calicivirus that is enzootic in rabbit populations worldwide, causing frequent epidemics with significant mortality rate up to $90 \%$ in rabbits older than 5 weeks $(127,228)$. Another important pathogen of this animal species is Myxoma virus which is a member of the Leporipoxvirus genus. Myxomatosis is an acute, systemic and often fatal disease of European rabbits characterized by blepharoconjuctivitis, swellings in the eyes, skin and genitals, listlessness and anorexia (229).

Nobivac ${ }^{\circledR}$ Myxo-RHD is a live chimeric bivalent vaccine that uses a Myxoma viral vector expressing the VP60 capsid protein of the classical 009 RHD viral strain. Nobivac ${ }^{\circledR}$ Myxo-RHD Plus contains a second recombinant Myxoma virus with the VP60 protein of the emerged variant MK 1899 (230). Nobivac ${ }^{\circledR}$ Myxo-RHD confers significant protection against both of the pathogens for 12 months after a single dose administration. In an immunization study all of the vaccinated animals seroconverted showing a strong humoral response against RHDV which is essential for the prevention of this viral disease in the challenged animals (231).

\section{DISCUSSION}

Historically, vaccines in human medicine have been in the wake of veterinary medicine as there are very limited licensed approved second and third generation vaccines in human medicine. The hepatitis B vaccine was the first example of a synthetic vaccine developed using recombinant DNA technology and was licensed in 1986; Hemophilus influenza B (HIB), the first conjugate vaccine, was licensed for medical usage in 1987; The Dengue tetravalent vaccine, trade name Dengvaxia, utilizes a live-attenuated tetravalent vaccine consisting of chimeric Dengue proteins combined with the non-structural genes of the Yellow Fever 17D vaccine strain. The rVSV-ZEBOV vaccine against Ebola Zaire, approved in 2019, is a live recombinant viral replication-competent Ebola vaccine consisting of a vesicular stomatitis virus backbone with the envelop glycoprotein of the Zaire ebolavirus in place of the VSV envelop glycoprotein. A heterologous 2-dose vaccination scheme with the Zabdeno (Ad26.ZEBOV) and Mvabea Ebola (MVA-BN-Filo) vaccines are approved for use in the EU. Zabdeno is the prime vaccination and is an adenovirus type 26 vector expressing the Ebola virus Mayinga variant's glycoprotein. MBA-BN-Filo serves as the boost immunization and is a non-replicating, recombinant, modified vaccinia Ankara (MVA) vector-based vaccine encoding glycoproteins from Zaire Ebola virus, Sudan virus, Marburg virus, and the nucleoprotein from the Tai Forest virus respectively (232).

In late 2020, the United Kingdom became the first sovereign country to approve Tozinameran INN, a messenger RNA vaccine (co-produced by Pfizer and BioNTech) indicated for the prevention of SARS-CoV-2 infection, the agent responsible for the COVID-19 pandemic (233). This is the first instance in which a gene-based technology has been licensed and approved for an infectious agent. Since then, and in the midst of the pandemic, other novel and third generation vaccine candidates have been approved for Emergency Use Authorization (EUA) or are undergoing final stages toward EUA application. At the time of writing, these candidates include the Moderna mRNA vaccine, mRNA-1273, and the adenovirus-vectored vaccine AZD1222 by AstraZeneca and Oxford University $(234,235)$.

Continuing to optimize delivery systems, and to enhance mucosal immunity, molecular adjuvants are crucial for the synergism of vaccine development. However, to remain within the scope of licensed novel technologies in veterinary medicine, the aforementioned components will only be briefly discussed as many are still in experimental stages.

One technology in which human medicine has arguably preceded veterinary medicine is the employment of virallike particles (VLPs). VLPs are non-infectious/void of genetic material, self-assembling complexes that bear antigens of interest and mimic the overall structure of a virus (236). The VLP technology has seen success as it activates the adaptive immune response via both MHC-I and MHC-II complexes and are consequently capable of stimulating robust CTLs and CD4+ $\mathrm{T}$ helper cells (237). Vaccines against human papillomavirus $\left(\right.$ Cervarix $^{\circledR}$, Gardasil ${ }^{\circledR}$, and Gardasil $9^{\circledR}$ ) and Hepatitis B virus (Sci-B-Vac ${ }^{\mathrm{TM}}$ ) also utilized the recombinant technology assembled onto a virus-like particle (VLPs) (238).

Nanoparticles (NPs), similar to VLPs, are a revolutionary delivery technology widely investigated for therapeutic drugs and vaccines. Characterized for their size $(<100 \mathrm{~nm})$, several types of NPs composed of gold, dendrimers, carbon polymers, an liposomes have been shown to improve vaccine efficacy, 
facilitate antigen uptake, and induce desired immunological responses (239). NPs offer several advantages: they can directly access lymphatic drainage systems for immune processing, can be modified to target specific subsets of immune cells, and can be delivered to specific intracellular compartments to hone in on specific immune pathways (240). As such, much of the success of the mRNA SARS-CoV-2 vaccine platform was the use of lipid NPs (241). Nonetheless, a comprehensive understanding of how NPs can be utilized to optimize vaccine delivery remains and many experimental NP candidates are currently being explored in clinical trials for influenza (NTC032293498, NCT3658629), and respiratory syncytial virus (NCT01960686, NCT02247726, NCT02624947) vaccines (240).

Some of the major gaps in vaccine development are the elicitation of mucosal immunity via induction of secretory IgA and the appropriate immune stimulation to the antigen via adjuvants. The vast majority of pathogens gain entry into hosts via mucosal sites, yet the majority of current vaccines provide partial or no protection at mucosal sites. In veterinary medicine, mucosal vaccines have been more successful as sprays and drinking water vaccines are routinely utilized, however, there are no licensed human vaccines for mucosal-transmitted pathogens (242). Vaccine-induced mucosal immunity is particularly challenging due to the difficulty in protecting and preserving antigen structural integrity and increasing the bioavailability of mucosal vaccines. Some experiments have seen success with the use of nanoparticle formulations by incorporating polyethylene glycol (PEG) (243). Chitosan, a non-toxic polymer has also been utilized in intranasally delivered Escherichia coli O157:H7 vaccine formations with similar success (244). Immunostimulating complexes (ISCOMs) are spherical cage-like experimental adjuvants composed of phospholipids, cholesterol, saponin, and protein antigens and have been particularly successful in mucosal immunizations resulting in secretory IgA and systemic immune responses $(245,246)$. This technology has been utilized in the equine influenza vaccine Equip ${ }^{\mathrm{TM}} \mathrm{F}$ (produced by Zoetis/Pfizer Animal Health), a subunit vaccine shown to stimulate both humoral and cell-mediated immunity $(247,248)$.

\section{REFERENCES}

1. Riedel S. Edward Jenner and the history of smallpox and vaccination. Proc Bayl Univ Med Cent. (2005) 18:21-5. doi: 10.1080/08998280.2005. 11928028

2. Lombard M, Pastoret PP, Moulin AM. A brief history of vaccines and vaccination. Rev Sci Tech. (2007) 26:29-48. doi: 10.20506/rst.26.1.1724

3. Tilly K, Rosa PA, Stewart PE. Biology of infection with Borrelia burgdorferi. Infect Dis Clin North Am. (2008) 22:217-34. doi: 10.1016/j.idc.2007.12.013

4. Pantaleo G, Koup RA. Correlates of immune protection in HIV-1 infection: what we know, what we don't know, what we should know. Nat Med. (2004) 10:806-10. doi: 10.1038/nm0804-806

5. Arvin AM. Humoral and cellular immunity to varicella-zoster virus: an overview. J Infect Dis. (2008) 197(Suppl.2):S58-60. doi: 10.1086/522123

6. Hoft DF. Tuberculosis vaccine development: goals, immunological design, and evaluation. Lancet. (2008) 372:16475. doi: 10.1016/S0140-6736(08)61036-3
A promising solution to combat poor immunogenicity, for DNA vaccines specifically, are molecular adjuvants. These generally comprise plasmid-encoded signaling molecules such as cytokines, chemokines, and immune costimulatory molecules, but newer approaches include gene knockdown and systems biology (249-251). For example, Interleukin-2 (IL-2) promote differentiation of naïve $\mathrm{T}$ cells into effector cells and facilitates the generation of memory T cells (20). Thus, IL-2 has been one of the most extensively studied molecular adjuvants and has shown increased immunogenicity for previously low-immunogenic vaccines such as HIV, influenza, and SARS-CoV (252-255). Other immunomodulatory cytokines being evaluated as molecu lar adjuvants are IL-15, IL-12, and MG-CSF $(250,252)$.

The evolution of vaccine technologies mirrors the continued and rigorous advancement toward safe, efficacious, stable, and cost-effective vaccines for existing and emerging infectious pathogens. Veterinary medicine continues to trail blaze the path as evident by the numerous novel technologies already employed.

\section{AUTHOR CONTRIBUTIONS}

VA, VP, PN, JN, and KM researched data for the article and substantially contributed to the discussion of content. VA, VP, and SG drafted and generated figures for the article. VA and $\mathrm{CK}$ wrote, reviewed, and edited the manuscript before submission. All authors contributed to the article and approved the submitted version.

\section{ACKNOWLEDGMENTS}

VA was funded through the United States Department of Agriculture (USDA) Animal and Plant Health Inspection Service's (APHIS) National Bio- and Agro- $\delta$ efense Facility Scientist Training Program. Work in the authors' laboratory was supported by the NIH/NIAID Centers of Excellence for Influenza Research and Surveillance (CEIRS), contract number HHSN272201400004C, and the Alabama Agricultural Experimental Station (AAES) at Auburn University.

7. Levin MJ, Oxman MN, Zhang JH, Johnson GR, Stanley H, Hayward AR, et al. Varicella-zoster virus-specific immune responses in elderly recipients of a herpes zoster vaccine. J Infect Dis. (2008) 197:825-35. doi: 10.1086/5 28696

8. Reyes-Sandoval A, Pearson FE, Todryk S, Ewer K. Potency assays for novel Tcell-inducing vaccines against malaria. Curr Opin Mol Ther. (2009) 11:72-80.

9. Pulendran B, Ahmed R. Immunological mechanisms of vaccination. Nat Immunol. (2011) 12:509-17. doi: 10.1038/ni.2039

10. Batista FD, Harwood NE. The who, how and where of antigen presentation to B cells. Nat Rev Immunol. (2009) 9:15-27. doi: 10.1038/nri2454

11. Lung P, Yang J, Li Q. Nanoparticle formulated vaccines: opportunities and challenges. Nanoscale. (2020) 12:5746-63. doi: 10.1039/C9NR08958F

12. Jiskoot W, Kersten GFA, Mastrobattista E, Slütter B. Vaccines. Pharmaceut Biotechnol Fundamental Appl. (2019) 14:281304. doi: 10.1007/978-3-030-00710-2_14

13. Alberts BJA, Lewis J, Raff M, Roberts K, Walter P. Molecular Biology of the Cell. New York, NY: Garland Science (2002). 
14. Belz GT, Carbone FR, Heath WR. Cross-presentation of antigens by dendritic cells. Crit Rev Immunol. (2002) 22:43948. doi: 10.1615/CritRevImmunol.v22.i5-6.50

15. Szabo SJ, Sullivan BM, Peng SL, Glimcher LH. Molecular mechanisms regulating Th1 immune responses. Annu Rev Immunol. (2003) 21:71358. doi: 10.1146/annurev.immunol.21.120601.140942

16. Kaiko GE, Horvat JC, Beagley KW, Hansbro PM. Immunological decision-making: how does the immune system decide to mount a helper T-cell response? Immunology. (2008) 123:32638. doi: 10.1111/j.1365-2567.2007.02719.x

17. Bernink J, Mjösberg J, Spits H. Th1- and Th2-like subsets of innate lymphoid cells. Immunol Rev. (2013) 252:133-8. doi: 10.1111/imr.12034

18. Mesquita DJr, Cruvinel WM, Resende LS, Mesquita FV, Silva NP, Câmara NO, et al. Follicular helper T cell in immunity and autoimmunity. Braz J Med Biol Res. (2016) 49:e5209. doi: 10.1590/1414-431×20165209

19. Qin L, Waseem TC, Sahoo A, Bieerkehazhi S, Zhou H, Galkina $\mathrm{EV}$, et al. Insights into the molecular mechanisms of $\mathrm{T}$ follicular helper-mediated immunity and pathology. Front Immunol. (2018) 9:1884. doi: 10.3389/fimmu.2018.01884

20. Janeway CAJPT, Mark W, Mark Shlomchik J. Immunobiology G.Science. 9th ed. Vol. 20 (2001). p. 445-86.

21. Meeusen EN, Walker J, Peters A, Pastoret PP, Jungersen G. Current status of veterinary vaccines. Clin Microbiol Rev. (2007) 20:489-510. doi: 10.1128/CMR.00005-07

22. Melnick JL. Advantages and disadvantages of killed and live poliomyelitis vaccines. Bull World Health Organ. (1978) 56:21-38.

23. Boyaka PN. Inducing mucosal IgA: a challenge for vaccine adjuvants and delivery systems. J Immunol. (2017) 199:916. doi: 10.4049/jimmunol.1601775

24. Blasco JM, Diaz R. Brucella melitensis Rev-1 vaccine as a cause of human brucellosis. Lancet. (1993) 342:805. doi: 10.1016/0140-6736(93)91571-3

25. Nielsen HS, Oleksiewicz MB, Forsberg R, Stadejek T, Botner A, Storgaard T. Reversion of a live porcine reproductive and respiratory syndrome virus vaccine investigated by parallel mutations. J Gen Virol. (2001) 82:126372. doi: 10.1099/0022-1317-82-6-1263

26. Brun A, Albina E, Barret T, Chapman DA, Czub M, Dixon LK, et al. Antigen delivery systems for veterinary vaccine development. Viral-vector based delivery systems. Vaccine. (2008) 26:6508-28. doi: 10.1016/j.vaccine.2008.09.044

27. Murti M, Krajden M, Petric M, Hiebert J, Hemming F, Hefford B, et al. Case of vaccine-associated measles five weeks post-immunisation, British Columbia, Canada, October 2013. Euro Surveill. (2013) 18:20649. doi: 10.2807/1560-7917.ES2013.18.49.20649

28. Arvas A. Vaccination in patients with immunosuppression. Turk pediatri arsivi. (2014) 49:181-5. doi: 10.5152/tpa.2014.2206

29. Ferraro B, Morrow MP, Hutnick NA, Shin TH, Lucke CE, Weiner DB. Clinical applications of DNA vaccines: current progress. Clin Infect Dis. (2011) 53:296-302. doi: 10.1093/cid/cir334

30. Small JC, Ertl HC. Viruses - from pathogens to vaccine carriers. Curr Opin Virol. (2011) 1:241-5. doi: 10.1016/j.coviro.2011.07.009

31. Doria-Rose NA, Haigwood NL. DNA vaccine strategies: candidates for immune modulation and immunization regimens. Methods. (2003) 31:20716. doi: 10.1016/S1046-2023(03)00135-X

32. Li J, Chen H, Wu N, Fan D, Liang G, Gao N, et al. Characterization of immune responses induced by inactivated, live attenuated and DNA vaccines against Japanese encephalitis virus in mice. Vaccine. (2013) 31:413642. doi: 10.1016/j.vaccine.2013.06.099

33. Chapman R, Rybicki EP. Use of a novel enhanced DNA vaccine vector for preclinical virus vaccine investigation. Vaccines. (2019) 7:20050. doi: 10.3390/vaccines 7020050

34. Mogensen TH. Pathogen recognition and inflammatory signaling in innate immune defenses. Clin Microbiol Rev. (2009) 22:24073. doi: 10.1128/CMR.00046-08

35. Kyriakis CS. Tomorrow's vector vaccines for small ruminants. Vet Microbiol. (2015) 181:47-52. doi: 10.1016/j.vetmic.2015.08.003

36. Sahin U, Karikó K, Türeci Ö. mRNA-based therapeutics - developing a new class of drugs. Nat Rev Drug Discov. (2014) 13:759-80. doi: 10.1038/nrd 4278
37. Lee J, Arun S, Kumar Jhan YY, Bishop CJ. Engineering DNA vaccines against infectious diseases. Acta Biomater. (2018) 80:31-47. doi: 10.1016/j.actbio.2018.08.033

38. Eric R, Miller NL, Paul C. Miller - Fowler's Zoo and Wild Animal Medicine Current Therapy Volume 9 E-Book. St. Lous, Missouri: Elsevier. (2019).

39. Smith GL, Murphy BR, Moss B. Construction and characterization of an infectious vaccinia virus recombinant that expresses the influenza hemagglutinin gene and induces resistance to influenza virus infection in hamsters. Proc Natl Acad Sci USA. (1983) 80:7155-9. doi: 10.1073/pnas.80.23.7155

40. Kieny MP, Lathe R, Drillien R, Spehner D, Skory S, Schmitt D, et al. Expression of rabies virus glycoprotein from a recombinant vaccinia virus. Nature. (1984) 312:163-6. doi: 10.1038/312163a0

41. Paoletti E. Applications of pox virus vectors to vaccination: an update. Proc Natl Acad Sci USA. (1996) 93:11349-53. doi: 10.1073/pnas.93.21.11349

42. Draper SJ, Cottingham MG, Gilbert SC. Utilizing poxviral vectored vaccines for antibody induction-progress and prospects. Vaccine. (2013) 31:422330. doi: 10.1016/j.vaccine.2013.05.091

43. Kreijtz JH, Gilbert SC, Sutter G. Poxvirus vectors. Vaccine. (2013) 31:42179. doi: 10.1016/j.vaccine.2013.06.073

44. Xiang ZQ, Yang Y, Wilson JM, Ertl HC. A replication-defective human adenovirus recombinant serves as a highly efficacious vaccine carrier Virology. (1996) 219:220-7. doi: 10.1006/viro.1996.0239

45. Rayner JO, Dryga SA, Kamrud KI. Alphavirus vectors and vaccination. Rev Med Virol. (2002) 12:279-96. doi: 10.1002/rmv.360

46. Pushko P, Parker M, Ludwig GV, Davis NL, Johnston RE, Smith JF. Replicon-helper systems from attenuated Venezuelan equine encephalitis virus: expression of heterologous genes in vitro and immunization against heterologous pathogens in vivo. Virology. (1997) 239:389-401. doi: 10.1006/viro.1997.8878

47. Capua I, Cattoli G. Diagnosing avian influenza infection in vaccinated populations by systems for differentiating infected from vaccinated animals (DIVA). Dev Biol. (2007) 130:137-43.

48. Suarez D. DIVA vaccination strategies for avian influenza virus. Avian Dis. (2012) 56:836-44. doi: 10.1637/10207-041512-Review.1

49. Kinker DR, Swenson SL, Wu LL, Zimmerman JJ. Evaluation of serological tests for the detection of pseudorabies $\mathrm{gE}$ antibodies during early infection. Vet Microbiol. (1997) 55:99-106. doi: 10.1016/S0378-1135(96)01308-9

50. Sykes JESDC. Pseudorabies, an overview. In: Canine and Feline Infectious Diseases. St. Louis, MI: Elseveir Inc. (2014). p. 258-60. doi: 10.1016/B978-1-4377-0795-3.00025-9

51. Freuling CM, Muller TF, Mettenleiter TC. Vaccines against pseudorabies virus (PrV). Vet Microbiol. (2017) 206:3-9. doi: 10.1016/j.vetmic.2016.11.019

52. Pardo MC, Bauman JE, Mackowiak M. Protection of dogs against canine distemper by vaccination with a canarypox virus recombinant expressing canine distemper virus fusion and hemagglutinin glycoproteins. Am J Vet Res. (1997) 58:833-6.

53. Larson LJ, Schultz RD. Effect of vaccination with recombinant canine distemper virus vaccine immediately before exposure under shelter-like conditions. Vet Ther. (2006) 7:113-8.

54. Shultz RD. A comparison of immunosuppressive effects of canine vaccines on lymphocyte responses to mitogens. In: Proceedings. 85th Annual Meeting of the CRWAD. Chicago, IL (2004)

55. Pardo MC, Tanner P, Bauman J, Silver K, Fischer L. Immunization of puppies in the presence of maternally derived antibodies against canine distemper virus. J Comp Pathol. (2007) 137(Suppl.1):S725. doi: 10.1016/j.jcpa.2007.04.015

56. Larson LJ, Schultz RD. Effect of vaccination with recombinant canine distemper virus vaccine immediately before exposure under shelter-like conditions. Vet Ther. (2006) 7:113-8.

57. Larson LJ, Schultz RD. Three-year duration of immunity in dogs vaccinated with a canarypox-vectored recombinant canine distemper virus vaccine. Vet Ther. (2007) 8:101-6.

58. Larson LJ, Schultz RD. Three-year serologic immunity against canine parvovirus type 2 and canine adenovirus type 2 in dogs vaccinated with a canine combination vaccine. Vet Ther. (2007) 8:305-10.

59. Coke RL, Backues KA, Hoover JP, Saliki JT, Ritchey JW, West GD. Serologic responses after vaccination of fennec foxes (Vulpes zerda) and meerkats 
(Suricata suricatta) with a live, canarypox-vectored canine distemper virus vaccine. J Zoo Wildl Med. (2005) 36:326-30. doi: 10.1638/04-039.1

60. Mead PS. Epidemiology of Lyme disease. Infect Dis Clin North Am. (2015) 29:187-210. doi: 10.1016/j.idc.2015.02.010

61. Summers BAAFS, Jacobson RH, Chang Y-F, Appel MJG, Straubinger RK. Histopathological studies of experimental Lyme disease in the dog. J Comp Pathol. (2005) 133:1-13. doi: 10.1016/j.jcpa.2004.11.006

62. Nowling JM, Philipp MT. Killing of Borrelia burgdorferi by antibody elicited by OspA vaccine is inefficient in the abscence of complement. Infect Immun. (1999) 67:443-5. doi: 10.1128/IAI.67.1.443-445.1999

63. Wilske B, Busch U, Fingerle V, Jauris-Heipke S, Preac V, Mursic Rossler D, et al. Immunological and molecular variability of OspA and OspImplications, C. for Borrelia vaccine development. Infection. (1996) 24:208-12. doi: 10.1007/BF01713341

64. Lovrich SD, Jobe DA, Schell RF, Callister SM. Borreliacidal OspC antibodies specific for a highly conserved epitope are immunodominant in human lyme disease and do not occur in mice or hamsters. Clin Diagn Lab Immunol. (2005) 12:746-51. doi: 10.1128/CDLI.12.6.746-751.2005

65. LaFleur RL, Dant JC, Wasmoen TL, Callister SM, Jobe DA, Lovrich SD, et al. Bacterin that induces anti-OspA and anti-OspC borreliacidal antibodies provides a high level of protection against canine Lyme disease. Clin Vaccine Immunol. (2009) 16:253-9. doi: 10.1128/CVI.00373-08

66. LaFleur RL, Callister SM, Dant JC, Jobe DA, Lovrich SD, Warner TF, et al. One-year duration of immunity induced by vaccination with a canine Lyme disease bacterin. Clin Vaccine Immunol. (2010) 17:8704. doi: 10.1128/CVI.00524-09

67. Ball EC. VANGUARD (R) crLyme: chimeric recombinant vaccine technology for broad-spectrum protection against canine Lyme disease. Zoetis Technical Bullet. (2015) 193:1-6.

68. Marconi RT, Honsberger N, Teresa M, Winkler Sobell N, King VL, Wappel S, et al. Field safety study of VANGUARD(R)crLyme: a vaccine for the prevention of Lyme disease in dogs. Vaccine X. (2020) 6:100080. doi: 10.1016/j.jvacx.2020.100080

69. Grosenbaugh DA, De Luca K, Durand PY, Feilmeier B, DeWitt K, Sigoillot-Claude C, et al. Characterization of recombinant OspA in two different Borrelia vaccines with respect to immunological response and its relationship to functional parameters. BMC Vet Res. (2018) 14:312. doi: 10.1186/s12917-018-1625-7

70. Dantas-Torres F, Miro G, Baneth G, Bourdeau P, Breitschwerdt E, Capelli G, et al. Canine leishmaniasis control in the context of one health. Emerg Infect Dis. (2019) 25:1-4. doi: 10.3201/eid2512.190164

71. Oliva G, Nieto J, Foglia Manzillo V, Cappiello S, Fiorentino E, Di Muccio T, et al. A randomised, double-blind, controlled efficacy trial of the LiESP/QA-21 vaccine in naive dogs exposed to two leishmania infantum transmission seasons. PLoS Negl Trop Dis. (2014) 8:e3213. doi: 10.1371/journal.pntd.0003213

72. Petitdidier E, Pagniez J, Papierok G, Vincendeau P, Lemesre JL, Bras-Goncalves R. Recombinant forms of leishmania amazonensis excreted/secreted promastigote surface antigen (PSA) induce protective immune responses in dogs. PLoS Negl Trop Dis. (2016) 10:e0004614. doi: 10.1371/journal.pntd.0004614

73. Moreno J, Vouldoukis I, Martin V, McGahie D, Cuisinier AM, Gueguen S. Use of a LiESP/QA-21 vaccine (CaniLeish) stimulates an appropriate Th1dominated cell-mediated immune response in dogs. PLoS Negl Trop Dis. (2012) 6:e1683. doi: 10.1371/journal.pntd.0001683

74. Martin V, Vouldoukis I, Moreno J, McGahie D, Gueguen S, Cuisinier AM. The protective immune response produced in dogs after primary vaccination with the LiESP/QA-21 vaccine (CaniLeish(R)) remains effective against an experimental challenge one year later. Vet Res. (2014) 45:69. doi: 10.1186/1297-9716-45-69

75. Moreno J, Vouldoukis I, Schreiber P, Martin V, McGahie D, Gueguen S, et al. Primary vaccination with the LiESP/QA-21 vaccine (CaniLeish) produces a cell-mediated immune response which is still present 1 year later. Vet Immunol Immunopathol. (2014) 158:199-207. doi: 10.1016/j.vetimm.2014.01.011

76. Fernandez Cotrina J, Iniesta V, Monroy I, Baz V, Hugnet C, Maranon F, et al. A large-scale field randomized trial demonstrates safety and efficacy of the vaccine LetiFend(R) against canine leishmaniosis. Vaccine. (2018) 36:1972-82. doi: 10.1016/j.vaccine.2018.02.111

77. Moafi M, Rezvan H, Sherkat R, Taleban R. Leishmania vaccines entered in clinical trials: a review of literature. Int J Prev Med. (2019) 10:95. doi: 10.4103/ijpvm.IJPVM_116_18

78. Regina-Silva S, Feres AM, Franca-Silva JC, Dias ES, Michalsky EM, de Andrade HM, et al. Field randomized trial to evaluate the efficacy of the Leish-Tec(R) vaccine against canine visceral leishmaniasis in an endemic area of Brazil. Vaccine. (2016) 34:2233-9. doi: 10.1016/j.vaccine.2016.03.019

79. Grimaldi G Jr, Teva A, Dos-Santos CB, Santos FN, Pinto ID, Fux B, et al. Field trial of efficacy of the Leish-tec(R) vaccine against canine leishmaniasis caused by Leishmania infantum in an endemic area with high transmission rates. PLoS ONE. (2017) 12:e0185438. doi: 10.1371/journal.pone.0185438

80. Fernandes CB, Junior JT, de Jesus C, Souza BM, Larangeira DF, Fraga $\mathrm{DB}$, et al. Comparison of two commercial vaccines against visceral leishmaniasis in dogs from endemic areas: IgG, and subclasses, parasitism, and parasite transmission by xenodiagnosis. Vaccine. (2014) 32:128795. doi: 10.1016/j.vaccine.2013.12.046

81. Toepp A, Larson M, Wilson G, Grinnage-Pulley T, Bennett CA, Leal-Lima B, et al. Randomized, controlled, double-blinded field trial to assess Leishmania vaccine effectiveness as immunotherapy for canine leishmaniosis. Vaccine. (2018) 36:6433-41. doi: 10.1016/j.vaccine.2018.08.087

82. Testasicca MC, dos Santos MS, Machado LM, Serufo AV, Doro D, Avelar D, et al. Antibody responses induced by Leish-Tec(R), an A2-based vaccine for visceral leishmaniasis, in a heterogeneous canine population. Vet Parasitol. (2014) 204:169-76. doi: 10.1016/j.vetpar.2014.04.025

83. Cacheiro-Llaguno C, Parody N, Renshaw-Calderon A, Osuna C, Alonso $\mathrm{C}$, Carnes J. Vaccination with LetiFend(R) reduces circulating immune complexes in dogs experimentally infected with L. infantum. Vaccine. (2019) 38:890-6 doi: 10.1016/j.vaccine.2019.10.078

84. Molano I, Alonso MG, Miron C, Redondo E, Requena JM, Soto M, et al. A Leishmania infantum multi-component antigenic protein mixed with live BCG confers protection to dogs experimentally infected with L. infantum. Vet Immunol Immunopathol. (2003) 92:1-13. doi: 10.1016/S0165-2427(02)00315-X

85. Carcelén J, Iniesta V, Fernández-Cotrina J, Serrano F, Parejo JC, Corraliza I, et al. The Chimerical Multi-Component $\mathrm{Q}$ protein from Leishmania in the absence of adjuvant protects dogs against an experimental Leishmania infantum infection. Vaccine. (2009) 27:5964-73. doi: 10.1016/j.vaccine.2009.07.069

86. Gradoni L. Canine Leishmania vaccines: still a long way to go. Vet Parasitol. (2015) 208:94-100. doi: 10.1016/j.vetpar.2015.01.003

87. Chhetri BK, Berke O, Pearl DL, Bienzle D. Comparison of the geographical distribution of feline immunodeficiency virus and feline leukemia virus infections in the United States of America (2000-2011). BMC Vet Res. (2013) 9:2. doi: 10.1186/1746-6148-9-2

88. Poulet H, Brunet S, Boularand C, Guiot AL, Leroy V, Tartaglia J, et al. Efficacy of a canarypox virus-vectored vaccine against feline leukaemia. Vet Rec. (2003) 153:141-5. doi: 10.1136/vr.153.5.141

89. Schlecht-Louf G, Mangeney M, El-Garch H, Lacombe V, Poulet $\mathrm{H}$, Heidmann T. A targeted mutation within the feline leukemia virus (FeLV) envelope protein immunosuppressive domain to improve a canarypox virus-vectored FeLV vaccine. J Virol. (2014) 88:992-1001. doi: 10.1128/JVI.02234-13

90. Tandon R, Cattori V, Gomes-Keller MA, Meli ML, Golder MC, Lutz $\mathrm{H}$, et al. Quantitation of feline leukaemia virus viral and proviral loads by TaqMan real-time polymerase chain reaction. J Virol Methods. (2005) 130:124-32. doi: 10.1016/j.jviromet.2005.06.017

91. El garch H, Richard S, Piras F, Leard T, Poulet H, Andreoni C, et al. Feline leukemia virus (FeLV)- specific IFN $\gamma+$ T-cell responses are induced in cats following transdermal vaccination with a recombinant FeLV vaccine. J Appl Res Vet Med. (2006) 4:100-8.

92. Grosenbaugh DA, Frances-Duvert V, Abedi S, Feilmeier B, Ru H, Poulet $\mathrm{H}$. Efficacy of a nonadjuvanted recombinant FeLV vaccine and two inactivated $\mathrm{FeLV}$ vaccines when subject to consistent virulent FeLV challenge conditions. Biologicals. (2017) 49:76-80. doi: 10.1016/j.biologicals. 2016.10.004 
93. Jas D, Frances-Duvert V, Vernes D, Guigal PM, Poulet H. Three-year duration of immunity for feline herpesvirus and calicivirus evaluated in a controlled vaccination-challenge laboratory trial. Vet Microbiol. (2015) 177:123-31. doi: 10.1016/j.vetmic.2015.03.009

94. Singh R, Singh KP, Cherian S, Saminathan M, Kapoor S, Manjunatha Reddy $\mathrm{GB}$, et al. Rabies - epidemiology, pathogenesis, public health concerns and advances in diagnosis and control: a comprehensive review. Vet Q. (2017) 37:212-51. doi: 10.1080/01652176.2017.1343516

95. Taylor J, Meignier B, Tartaglia J, Languet B, VanderHoeven J, Franchini $\mathrm{G}$, et al. Biological and immunogenic properties of a canarypox-rabies recombinant, ALVAC-RG (vCP65) in non-avian species. Vaccine. (1995) 13:539-49. doi: 10.1016/0264-410X(94)00028-L

96. Jas D, Coupier C, Toulemonde CE, Guigal PM, Poulet H. Threeyear duration of immunity in cats vaccinated with a canarypoxvectored recombinant rabies virus vaccine. Vaccine. (2012) 30:69916. doi: 10.1016/j.vaccine.2012.09.068

97. Doddy FD, Glickman LT, Glickman NW, Janovitz EB. Feline fibrosarcomas at vaccination sites and non-vaccination sites. J Comparat Pathol. (1996) 114:165-74. doi: 10.1016/S0021-9975(96)80005-3

98. Soboll G, Hussey SB, Minke JM, Landolt GA, Hunter JS, Jagannatha S, et al. Onset and duration of immunity to equine influenza virus resulting from canarypox-vectored (ALVAC) vaccination. Vet Immunol Immunopathol. (2010) 135:100-7. doi: 10.1016/j.vetimm.2009.11.007

99. Gildea S, Arkins S, Walsh C, Cullinane A. A comparison of antibody responses to commercial equine influenza vaccines following primary vaccination of Thoroughbred weanlings-a randomised blind study. Vaccine. (2011) 29:9214-23. doi: 10.1016/j.vaccine.2011.09.101

100. Edlund Toulemonde C, Daly J, Sindle T, Guigal PM, Audonnet JC, Minke JM. Efficacy of a recombinant equine influenza vaccine against challenge with an American lineage H3N8 influenza virus responsible for the 2003 outbreak in the United Kingdom. Vet Rec. (2005) 156:367-71. doi: 10.1136/vr.156.12.367

101. Minke JM, El-Hage CM, Tazawa P, Homer D, Lemaitre L, Cozette V, et al. Evaluation of the response to an accelerated immunisation schedule using a canarypox-vectored equine influenza vaccine, shortened interdose intervals and vaccination of young foals. Aust Vet J. (2011) 89(Suppl.1):1379. doi: 10.1111/j.1751-0813.2011.00767.x

102. Dilai M, Piro M, El Harrak M, Fougerolle S, Dehhaoui M, Dikrallah A, et al. Impact of mixed equine influenza vaccination on correlate of protection in horses. Vaccines. (2018) 6:40071. doi: 10.3390/vaccines6040071

103. Gildea S, Quinlivan M, Murphy BA, Cullinane A. Humoral response and antiviral cytokine expression following vaccination of thoroughbred weanlings-a blinded comparison of commercially available vaccines. Vaccine. (2013) 31:5216-22. doi: 10.1016/j.vaccine.2013.08.083

104. Johnston LJ, Halliday GM, King NJ. Langerhans cells migrate to local lymph nodes following cutaneous infection with an arbovirus. J Invest Dermatol. (2000) 114:560-8. doi: 10.1046/j.1523-1747.2000.00904.x

105. Mackenzie JS, Gubler DJ, Petersen LR. Emerging flaviviruses: the spread and resurgence of Japanese encephalitis, West Nile and dengue viruses. Nat Med. (2004) 10(12 Suppl.):S98-109. doi: 10.1038/nm1144

106. Mehlhop E, Whitby K, Oliphant T, Marri A, Engle M, Diamond MS. Complement activation is required for induction of a protective antibody response against West Nile virus infection. J Virol. (2005) 79:746677. doi: 10.1128/JVI.79.12.7466-7477.2005

107. El Garch H, Minke JM, Rehder J, Richard S, Edlund C, Toulemonde Dinic $\mathrm{S}$, et al. A West Nile virus (WNV) recombinant canarypox virus vaccine elicits WNV-specific neutralizing antibodies and cell-mediated immune responses in the horse. Vet Immunol Immunopathol. (2008) 123:2309. doi: 10.1016/j.vetimm.2008.02.002

108. Tardei G, Ruta S, Chitu V, Rossi C, Tsai TF, Cernescu C. Evaluation of immunoglobulin $\mathrm{M}$ (IgM) and IgG enzyme immunoassays in serologic diagnosis of West Nile Virus infection. J Clin Microbiol. (2000) 38:22329. doi: 10.1128/JCM.38.6.2232-2239.2000

109. Diamond MS, Sitati EM, Friend LD, Higgs S, Shrestha B, Engle M. A critical role for induced IgM in the protection against West Nile virus infection. $J$ Exp Med. (2003) 198:1853-62. doi: 10.1084/jem.20031223

110. De Filette M, Ulbert S, Diamond MS, Sanders NN. Recent progress in West Nile virus diagnosis and vaccination. Vet Res. (2012) 43:16. doi: 10.1186/1297-9716-43-16
111. Shrestha B, Wang T, Samuel MA, Whitby K, Craft J, Fikrig E, et al. Gamma interferon plays a crucial early antiviral role in protection against West Nile virus infection. J Virol. (2006) 80:5338. doi: 10.1128/JVI.00274-06

112. Minke JM, Siger L, Karaca K, Austgen L, Gordy P, Bowen R, et al. Recombinant canarypoxvirus vaccine carrying the prM/E genes of West Nile virus protects horses against a West Nile virus-mosquito challenge. Arch Virol Suppl. (2004) 18:221-30. doi: 10.1007/978-3-7091-0572-6_20

113. Siger L, Bowen RA, Karaca K, Murray MJ, Gordy PW, Loosmore SM, et al. Assessment of the efficacy of a single dose of a recombinant vaccine against West Nile virus in response to natural challenge with West Nile virus-infected mosquitoes in horses. Am J Vet Res. (2004) 65:145962. doi: 10.2460/ajvr.2004.65.1459

114. Davis BS, Chang GJ, Cropp B, Roehrig JT, Martin DA, Mitchell CJ, et al. West Nile virus recombinant DNA vaccine protects mouse and horse from virus challenge and expresses in vitro a noninfectious recombinant antigen that can be used in enzyme-linked immunosorbent assays. J Virol. (2001) 75:4040-7. doi: 10.1128/JVI.75.9.4040-4047.2001

115. Dunn MD, Rossi SL, Carter DM, Vogt MR, Mehlhop E, Diamond MS et al. Enhancement of anti-DIII antibodies by the C3d derivative P28 results in lower viral titers and augments protection in mice. Virol J. (2010) 7:95. doi: 10.1186/1743-422X-7-95

116. Amanna IJ, Slifka MK. Current trends in West Nile virus vaccine development. Expert Rev Vaccines. (2014) 13:589608. doi: 10.1586/14760584.2014.906309

117. Frey J. Virulence in Actinobacillus pleuropneumoniae and RTX toxins. Trends Microbiol. (1995) 3:257-61. doi: 10.1016/S0966-842X(00)88939-8

118. Blackall PJ, Klaasen HL, van den Bosch H, Kuhnert P, Frey J. Proposal of a new serovar of Actinobacillus pleuropneumoniae: serovar 15. Vet Microbiol. (2002) 84:47-52. doi: 10.1016/S0378-1135(01)00428-X

119. Chiers K, van Overbeke I, De Laender P, Ducatelle R, Carel S, Haesebrouck F. Effects of endobronchial challenge with Actinobacillus pleuropneumoniae serotype 9 of pigs vaccinated with inactivated vaccines containing the Apx toxins. Vet Q. (1998) 20:65-9. doi: 10.1080/01652176.1998.9694841

120. Cruijsen T, van Leengoed LA, Kamp EM, Bartelse A, Korevaar A, Verheijden JH. Susceptibility to Actinobacillus pleuropneumoniae infection in pigs from an endemically infected herd is related to the presence of toxin-neutralizing antibodies. Vet Microbiol. (1995) 47:219-28. doi: 10.1016/0378-1135(95)00109-3

121. Sjolund M, Wallgren P. Field experience with two different vaccination strategies aiming to control infections with Actinobacillus pleuropneumoniae in a fattening pig herd. Acta Vet Scand. (2010) 52:23 doi: $10.1186 / 1751-0147-52-23$

122. Del Pozo Sacristán R, Michiels A, Martens M, Haesebrouck F, Maes D. Efficacy of vaccination against Actinobacillus pleuropneumoniae in two Belgian farrow-to-finish pig herds with a history of chronic pleurisy. Vet Rec. (2014) 174:302. doi: 10.1136/vr.101961

123. Tumamao JQ, Bowles RE, van den Bosch H, Klaasen HL, Fenwick BW, Storie GJ, et al. Comparison of the efficacy of a subunit and a live streptomycindependent porcine pleuropneumonia vaccine. Aust Vet J. (2004) 82:3704. doi: 10.1111/j.1751-0813.2004.tb11108.x

124. Van Overbeke I, Chiers K, Ducatelle R, Haesebrouck F. Effect of endobronchial challenge with Actinobacillus pleuropneumoniae serotype 9 of pigs vaccinated with a vaccine containing Apx toxins and transferrinbinding proteins. J Vet Med B Infect Dis Vet Public Health. (2001) 48:1520. doi: 10.1046/j.1439-0450.2001.00419.x

125. Rosell C, Segales J, Plana-Duran J, Balasch M, Rodriguez-Arrioja GM, Kennedy S, et al. Pathological, immunohistochemical, and in situ hybridization studies of natural cases of postweaning multisystemic wasting syndrome (PMWS) in pigs. J Comp Pathol. (1999) 120:5978. doi: $10.1053 /$ jcpa.1998.0258

126. Olvera A, Cortey M, Segales J. Molecular evolution of porcine circovirus type 2 genomes: phylogeny and clonality. Virology. (2007) 357:17585. doi: 10.1016/j.virol.2006.07.047

127. Maclachlan James NaEJD. Fener's Veterinary Virology. London: Academic Press; Elsevier Academic Press (2010).

128. Felberbaum RS. The baculovirus expression vector system: a commercial manufacturing platform for viral vaccines and gene therapy vectors. Biotechnol J. (2015) 10:702-14. doi: 10.1002/biot.201400438 
129. Gillespie J, Opriessnig T, Meng XJ, Pelzer K, Buechner-Maxwell V. Porcine circovirus type 2 and porcine circovirus-associated disease. J Vet Intern Med. (2009) 23:1151-63. doi: 10.1111/j.1939-1676.2009.0389.x

130. Roof Michael B, Eichmeyer Marc Allan HPWU, Gregory Paul N, Merrill Lynn S. Use of a PCV2 immunogenic composition for lessening clinical symptoms in pigs. BIVI. US-9987349-B2. St. Joseph, MO (2018). Available online at: https://patentimages.storage.googleapis.com/16/19/b1/ 31636a686043fd/US9987349.pdf

131. Fenaux M, Opriessnig T, Halbur PG, Elvinger F, Meng XJ. A chimeric porcine circovirus (PCV) with the immunogenic capsid gene of the pathogenic PCV type 2 (PCV2) cloned into the genomic backbone of the nonpathogenic PCV1 induces protective immunity against PCV2 infection in pigs. J Virol. (2004) 78:6297-303. doi: 10.1128/JVI.78.12.6297-6303.2004

132. Seo HW, Oh Y, Han K, Park C, Chae C. Reduction of porcine circovirus type 2 (PCV2) viremia by a reformulated inactivated chimeric PCV1-2 vaccineinduced humoral and cellular immunity after experimental PCV2 challenge. BMC Vet Res. (2012) 8:194. doi: 10.1186/1746-6148-8-194

133. Hemann M, Beach NM, Meng XJ, Wang C, Halbur PG, Opriessnig T. A liveattenuated and an inactivated chimeric porcine circovirus (PCV)1-2 vaccine are both effective at inducing a humoral immune response and reducing PCV2 viremia and intrauterine infection in female swine of breeding age. Can J Vet Res. (2014) 78:8-16.

134. Hoblet KH, Miller GY, Bartter NG. Economic assessment of a pseudorabies epizootic, breeding herd removal/repopulation, and downtime in a commercial swine herd. J Am Vet Med Assoc. (1987) 190:405-9.

135. International I. Procilis Begonia Intervet International. Boxmeer (2002).

136. Pensaert M, Labarque G, Favoreel H, Nauwynck H. Aujeszky's disease vaccination and differentiation of vaccinated from infected pigs. Dev Biol. (2004) 119:243-54.

137. Zeng T, Torrents WJ, Martinez D, Pedrazuela CR. Vaccination with PRV vaccine (AUSKIPRA (R) GN; Bartha k61 strain), reduced virus shedding when challenge against Chinese PRV variant (AH02 strain). In: APVS Congress, Manila. (2015).

138. Zeng T, Torrents WJ, Martinez D, Pedrazuela CR, Gale I. PRV vaccine AUSKIPRA $®$ GN (A3 solvent; Bartha k61 strain) provide quick and strong protection against Chinese PRV variant. In: APVS, Manila. (2015).

139. Szweda Wea. The role of vaccinations using deleted vaccines in decreasing the spread of Aujeszky's disease virus in pig farms covered within the" vaccination-eradication programme. Medycyna Weterynaryjna. (2000) 56.4:229-34.

140. Quilitis MTD, Torres I, Bautista C, Magcalas J, Maldonado J, Llopart D. Retrospective study on the prevalence of Aujeszky's disease in major pig producing provinces in the Philippines (2006-2010). In: IPVS, Korea. (2012).

141. Risatti GR, Borca MV, Kutish GF, Lu Z, Holinka LG, French RA, et al. The E2 glycoprotein of classical swine fever virus is a virulence determinant in swine. J Virol. (2005) 79:3787-96. doi: 10.1128/JVI.79.6.3787-3796.2005

142. Borca MV, Holinka LG, Ramirez-Medina E, Risatti GR, Vuono EA, Berggren $\mathrm{KA}$, et al. Identification of structural glycoprotein E2 domain critical to mediate replication of Classical Swine Fever Virus in SK6 cells. Virology. (2019) 526:38-44. doi: 10.1016/j.virol.2018.10.004

143. Luo Y, Li S, Sun Y, Qiu H-J. Classical swine fever in China: a minireview. Vet Microbiol. (2014) 172:1-6. doi: 10.1016/j.vetmic.2014.04.004

144. Blome S, Staubach C, Henke J, Carlson J, Beer M. Classical swine fever-an updated review. Viruses. (2017) 9:40086. doi: 10.3390/v9040086

145. Brown VR, Bevins SN. A Review of classical swine fever virus and routes of introduction into the United States and the potential for virus establishment. Front Vet Sci. (2018) 5:31. doi: 10.3389/fvets.2018.00031

146. Reimann I, Depner K, Trapp S, Beer M. An avirulent chimeric Pestivirus with altered cell tropism protects pigs against lethal infection with classical swine fever virus. Virology. (2004) 322:143-57. doi: 10.1016/j.virol. 2004.01.028

147. Hulst MM, Moormann RJ. Inhibition of pestivirus infection in cell culture by envelope proteins $\mathrm{E}(\mathrm{rns})$ and $\mathrm{E} 2$ of classical swine fever virus: $\mathrm{E}(\mathrm{rns})$ and E2 interact with different receptors. J Gen Virol. (1997) 78:277987. doi: 10.1099/0022-1317-78-11-2779

148. Blome S, Wernike K, Reimann I, König P, Moß C, Beer M. A decade of research into classical swine fever marker vaccine CP7 E2alf
(Suvaxyn ${ }^{\circledR}$ CSF Marker): a review of vaccine properties. Vet Res. (2017) 48:51. doi: 10.1186/s13567-017-0457-y

149. Koenig P, Lange E, Reimann I, Beer M. CP7_E2alf: A safe and efficient marker vaccine strain for oral immunisation of wild boar against Classical swine fever virus (CSFV). Vaccine. (2007) 25:33919. doi: 10.1016/j.vaccine.2006.12.052

150. Xia H, Harimoorthy R, Vijayaraghavan B, Blome S, Widen F, Beer M, et al. Differentiation of classical swine fever virus infection from CP7_E2alf marker vaccination by a multiplex microsphere immunoassay. Clin Vaccine Immunol. (2015) 22:65-71. doi: 10.1128/CVI.00271-14

151. Renson P, Le M, Dimna Keranflech A, Cariolet R, Koenen F, Le Potier MF. CP7_E2alf oral vaccination confers partial protection against early classical swine fever virus challenge and interferes with pathogeny-related cytokine responses. Vet Res. (2013) 44:9. doi: 10.1186/1297-9716-44-9

152. Gabriel C, Blome S, Urniza A, Juanola S, Koenen F, Beer M. Towards licensing of CP7_E2alf as marker vaccine against classical swine fever-duration of immunity. Vaccine. (2012) 30:2928-36. doi: 10.1016/j.vaccine.2012.02.065

153. Cox MMJ. Recombinant protein vaccines produced in insect cells. Vaccine (2012) 30:1759-66. doi: 10.1016/j.vaccine.2012.01.016

154. Ahrens U, Kaden V, Drexler C, Visser N. Efficacy of the classical swine fever (CSF) marker vaccine Porcilis ${ }^{\circledR}$ Pesti in pregnant sows. Vet Microbiol. (2000) 77:83-97. doi: 10.1016/S0378-1135(00)00265-0

155. Depner KR, Bouma A, Koenen F, Klinkenberg D, Lange E, de $\mathrm{H}$, et al. Classical swine fever (CSF) marker vaccine: Trial IChallenge, I. study in pregnant sows. Vet Microbiol. (2001) 83:107-20. doi: 10.1016/S0378-1135(01)00410-2

156. Vlasova AN, Marthaler D, Wang Q, Culhane MR, Rossow KD, Rovira A, et al. Distinct characteristics and complex evolution of PEDV strains, North America, May 2013-February 2014. Emerg Infect Dis. (2014) 20:16208. doi: 10.3201/eid2010.140491

157. Antas M, Wozniakowski G. Current status of porcine epidemic diarrhoea (PED) in European Pigs. J Vet Res. (2019) 63:46570. doi: 10.2478/jvetres-2019-0064

158. Li S, Yang J, Zhu Z, Zheng H. Porcine epidemic diarrhea virus and the host innate immune response. Pathogens. (2020) 9:50367. doi: 10.3390/pathogens 9050367

159. Chang SH, Bae JL, Kang TJ, Kim J, Chung GH, Lim CW, et al. Identification of the epitope region capable of inducing neutralizing antibodies against the porcine epidemic diarrhea virus. Mol Cells. (2002) 14:295-9.

160. Bosch BJ, van der Zee R, de Haan CA, Rottier PJ. The coronavirus spike protein is a class I virus fusion protein: structural and functional characterization of the fusion core complex. J Virol. (2003) 77:880111. doi: 10.1128/JVI.77.16.8801-8811.2003

161. Mogler MA, Gander JR, Ray DD, Harris DLH. Vaccination of PEDV-naive dams with a replicon RNA particle vaccine protects suckling piglets from challenge. In: PRSS PED Symposium Poster Presentation (Ames, IA). (2014).

162. Vander Veen RL, Harris DL, Kamrud KI. Alphavirus replicon vaccines. Anim Health Res Rev. (2012) 13:1-9. doi: 10.1017/S1466252312000011

163. Crawford K, Lager K, Kulshreshtha V, Miller L, Faaberg K. Status of vaccines for porcine epidemic diarrhea virus in the United States and Canada. Virus Res. (2016) 226:108-16. doi: 10.1016/j.virusres.2016.08.005

164. Greiner L, Connor J, Graham A, Mellor J, Lowe J. Evaluation of a PED vaccine on piglet mortality and sow immunity. In: 46th Proceedings of the 2015 Meeting of the American Association of Swine Veterinarians Orlando, Florida. (2015).

165. Ma W, Lager KM, Vincent AL, Janke BH, Gramer MR, Richt JA. The role of swine in the generation of novel influenza viruses. Zoonoses Public Health. (2009) 56:326-37. doi: 10.1111/j.1863-2378.2008.01217.x

166. Kyriakis CS, Brown IH, Foni E, Kuntz-Simon G, Maldonado J, Madec F, et al. Virological surveillance and preliminary antigenic characterization of influenza viruses in pigs in five European countries from 2006 to 2008. Zoonoses Public Health. (2011) 58:93-101. doi: 10.1111/j.1863-2378.2009.01301.x

167. Nelson MI, Viboud C, Vincent AL, Culhane MR, Detmer SE, Wentworth DE, et al. Global migration of influenza A viruses in swine. Nat Commun. (2015) 6:6696. doi: $10.1038 /$ ncomms7696 
168. Kyriakis CS, Zhang M, Wolf S, Jones LP, Shim BS, Chocallo AH, et al. Molecular epidemiology of swine influenza A viruses in the Southeastern United States, highlights regional differences in circulating strains. Vet Microbiol. (2017) 211:174-9. doi: 10.1016/j.vetmic.2017.10.016

169. Strauss JH, Strauss EG. The alphaviruses: gene expression, replication, and evolution. Microbiol Rev. (1994) 58:491562. doi: 10.1128/MR.58.3.491-562.1994

170. Hooper JW, Ferro AM, Golden JW, Silvera P, Dudek J, Alterson K, et al. Molecular smallpox vaccine delivered by alphavirus replicons elicits protective immunity in mice and non-human primates. Vaccine. (2009) 28:494-511. doi: 10.1016/j.vaccine.2009.09.133

171. Bosworth B, Erdman MM, Stine DL, Harris I, Irwin C, Jens M, et al. Replicon particle vaccine protects swine against influenza. Comp Immunol Microbiol Infect Dis. (2010) 33:e99-103. doi: 10.1016/j.cimid.2010.05.002

172. Erdman MM, Kamrud KI, Harris DL, Smith J. Alphavirus replicon particle vaccines developed for use in humans induce high levels of antibodies to influenza virus hemagglutinin in swine: proof of concept. Vaccine. (2010) 28:594-6. doi: 10.1016/j.vaccine.2009.10.015

173. Vander Veen RL, Loynachan AT, Mogler MA, Russell BJ, Harris DL, Kamrud KI. Safety, immunogenicity, and efficacy of an alphavirus replicon-based swine influenza virus hemagglutinin vaccine. Vaccine. (2012) 30:194450. doi: 10.1016/j.vaccine.2012.01.030

174. Knight-Jones TJ, Rushton J. The economic impacts of foot and mouth disease - what are they, how big are they and where do they occur? Prev Vet Med. (2013) 112:161-73. doi: 10.1016/j.prevetmed.2013.07.013

175. Grubman MJea. Adenovirus serotype 5-vectored foot-and-mouth diseaes subunit vaccines: the first decade. Futur Virol. (2010) 5:51-64. doi: 10.2217/fvl.09.68

176. Shutta Cea. Mutliple efficacy studies of an adenovirus-vectored foot-andmouth disease virus serotype A24 subunit vaccine in cattle using homologous challenge. Vaccine. (2016) 34:3214-20. doi: 10.1016/j.vaccine.2015.12.018

177. Change SHea. Use of ENABLE(R) Adjuvant to increase the potency of an adenovirus-vectored foot-and-mouth disease virus serotype A subunit. Vaccine. (2018) 36:1078-84. doi: 10.1016/j.vaccine.2018.01.026

178. Barrera J, Brake DA, Kamicker BJ, Purcell C, Kaptur R Jr, Schieber T, et al. Safety profile of a replication-deficient human adenovirus-vectored footand-mouth disease virus serotype A24 subunit vaccine in cattle. Transbound Emerg Dis. (2018) 65:447-55. doi: 10.1111/tbed.12724

179. Neilan JG, Schutta C, Barrera J, Pisano M, Zsak L, Hartwig E, et al. Efficacy of an adenovirus-vectored foot-and-mouth disease virus serotype A subunit vaccine in cattle using a direct contact transmission model. BMC Vet Res. (2018) 14:254. doi: 10.1186/s12917-018-1582-1

180. Engels M, Ackermann M. Pathogenesis of ruminant herpesvirus infections. Vet Microbiol. (1996) 53:3-15. doi: 10.1016/S0378-1135(96)01 230-8

181. Castrucci G, Frigeri F, Salvatori D, Ferrari M, Dico ML, Rotola A, et al. A study on latency in calves by five vaccines against bovine herpesvirus-1 infection. Comp Immunol Microbiol Infect Dis. (2002) 25:205-15. doi: 10.1016/S0147-9571(02)00 014-0

182. Petrini S, Iscaro C, Righi C. Antibody responses to bovine alphaherpesvirus 1 (BoHV-1) in passively immunized calves. Viruses. (2019) 11:10023. doi: 10.3390/v11010023

183. Bosch JC, Kaashoek MJ, van Oirschot JT. Inactivated bovine herpesvirus 1 marker vaccines are more efficacious in reducing virus excretion after reactivation than a live marker vaccine. Vaccine. (1997) 15:15127. doi: 10.1016/S0264-410X(97)00092-3

184. Kerkhofs P, Renjifo X, Toussaint JF, Letellier C, Vanopdenbosch E, Wellemans G. Enhancement of the immune response and virological protection of calves against bovine herpesvirus type 1 with an inactivated gE-deleted vaccine. Vet Rec. (2003) 152:681-6. doi: 10.1136/vr.152.22.68

185. Makoschey B, Beer M. A live bovine herpesvirus-1 marker vaccine is not shed after intramuscular vaccination. Berl Munch Tierarztl Wochenschr. (2007) $120: 480-2$.

186. Petrini S, Righi C, Iscaro C, Viola G, Gobbi P, Scoccia E, et al. Evaluation of passive immunity induced by immunisation using two inactivated gEdeleted marker vaccines against infectious bovine rhinotracheitis (IBR) in calves. Vaccines. (2020) 8:10014. doi: 10.3390/vaccines8010014
187. Webster RG, Taylor J, Pearson J, Rivera E, Paoletti E. Immunity to Mexican $\mathrm{H} 5 \mathrm{~N} 2$ avian influenza viruses induced by a fowl pox-H5 recombinant. Avian Dis. (1996) 40:461-5. doi: 10.2307/1592246

188. Swayne DE, Beck JR, Mickle TR. Efficacy of recombinant fowl poxvirus vaccine in protecting chickens against a highly pathogenic Mexican-origin H5N2 avian influenza virus. Avian Dis. (1997) 41:910-22. doi: $10.2307 / 1592346$

189. Swayne DE, Beck JR, Kinney N. Failure of a recombinant fowl poxvirus vaccine containing an avian influenza hemagglutinin gene to provide consistent protection against influenza in chickens preimmunized with a fowl pox vaccine. Avian Dis. (2000) 44:132-7. doi: 10.2307/1592516

190. Kilany W, Dauphin G, Selim A, Tripodi A, Samy M, Sobhy H, et al. Protection conferred by recombinant turkey herpesvirus avian influenza (rHVT-H5) vaccine in the rearing period in two commercial layer chicken breeds in Egypt. Avian Pathol. (2014) 43:514-23. doi: 10.1080/03079457.2014.966302

191. Palya V, Tatar-Kis T, Walkone E, Kovacs Kiss I, Homonnay Z, Gardin $\mathrm{Y}$, et al. Efficacy of a recombinant turkey herpesvirus AI (H5) vaccine in preventing transmission of heterologous highly pathogenic H5N8 Clade 2.3.4.4b challenge virus in commercial broilers and layer pullets. J Immunol Res. (2018) 2018:3143189. doi: 10.1155/2018/3143189

192. Rahman AU, Habib M, Shabbir MZ. Adaptation of Newcastle Disease Virus (NDV) in feral birds and their potential role in interspecies transmission. Open Virol J. (2018) 12:52-68. doi: 10.2174/1874357901812010052

193. Dortmans JC, Koch G, Rottier PJ, Peeters BP. Virulence of Newcastle disease virus: what is known so far? Vet Res. (2011) 42:122. doi: $10.1186 / 1297-9716-42-122$

194. Abdisa T, Tagesu T. Review on Newcastle disease of poultry and its public health importance. J Vet Sci Technol. (2017) 8:441. doi: 10.4172/2157-7579.1000441

195. Morgan RW, Gelb JJr, Schreurs CS, Lutticken D, Rosenberger JK, Sondermeijer PJ, et al. Protection of chickens from Newcastle and Marek's diseases with a recombinant herpesvirus of turkeys vaccine expressing the Newcastle disease virus fusion protein. Avian Dis. (1992) 36:85870. doi: $10.2307 / 1591544$

196. Jeon WJ, Lee EK, Joh SJ, Kwon JH, Yang CB, Yoon YS, et al. Very virulent infectious bursal disease virus isolated from wild birds in Korea: epidemiological implications. Virus Res. (2008) 137:1536. doi: 10.1016/j.virusres.2008.06.013

197. Dey S, Pathak DC, Ramamurthy N, Maity HK, Chellappa MM. Infectious bursal disease virus in chickens: prevalence, impact, and management strategies. Vet Med. (2019) 10:85-97. doi: 10.2147/VMRR.S185159

198. Jarosinski KW, Tischer BK, Trapp S, Osterrieder N. Marek's disease virus: lytic replication, oncogenesis and control. Expert Rev Vaccines. (2006) 5:76172. doi: $10.1586 / 14760584.5 .6 .761$

199. Gowthaman V, Kumar S, Koul M, Dave U, Murthy T, Munuswamy P, et al. Infectious laryngotracheitis: etiology, epidemiology, pathobiology, and advances in diagnosis and control - a comprehensive review. Vet Q. (2020) 40:140-61. doi: 10.1080/01652176.2020.1759845

200. van Hulten MCW, Cruz-Coy J, Gergen L, Pouwels H, ten Dam GB, Verstegen I, et al. Efficacy of a turkey herpesvirus double construct vaccine (HVT-ND-IBD) against challenge with different strains of Newcastle disease, infectious bursal disease and Marek's disease viruses. Avian Pathol. (2021) 50:18-30. doi: 10.1080/03079457.2020. 1828567

201. Sun HL, Wang YF, Tong GZ, Zhang PJ, Miao DY, Zhi HD, et al. Protection of chickens from Newcastle disease and infectious laryngotracheitis with a recombinant fowlpox virus co-expressing the F, HN genes of Newcastle disease virus and $\mathrm{gB}$ gene of infectious laryngotracheitis virus. Avian Dis. (2008) 52:111-7. doi: 10.1637/7998-041807-Reg

202. Chang C-J. Immune sensing of DNA and strategies for fish DNA vaccine development. Fish Shellfish Immunol. (2020) 101:252-60. doi: 10.1016/j.fsi.2020.03.064

203. Kobiyama K, Jounai N, Aoshi T, Tozuka M, Takeshita F, Coban C, et al. Innate immune signaling by, and genetic adjuvants for DNA vaccination. Vaccines. (2013) 1:278-92. doi: 10.3390/vaccines 1030278

204. Skinner LA, Schulte PM, LaPatra SE, Balfry SK, McKinley RS. Growth and performance of Atlantic salmon, Salmo salar L., following 
administration of a rhabdovirus DNA vaccine alone or concurrently with an oil-adjuvanted, polyvalent vaccine. J Fish Dis. (2008) 31:687-97. doi: 10.1111/j.1365-2761.2008.00945.x

205. Thim HL, Villoing S, McLoughlin M, Christie KE, Grove S, Frost P, et al. Vaccine adjuvants in fish vaccines make a difference: comparing three adjuvants (montanide ISA763A Oil, CpG/Poly I:C Combo and VHSV Glycoprotein) alone or in combination formulated with an inactivated whole salmonid alphavirus antigen. Vaccines. (2014) 2:22851. doi: $10.3390 /$ vaccines 2020228

206. Salonius K, Simard N, Harland R, Ulmer J. The road to licensure of a DNA vaccine. Curr Opin Investigat Drugs. (2007) 8:635-41.

207. Corbeil S, Lapatra SE, Anderson ED, Jones J, Vincent B, Hsu YL, et al. Evaluation of the protective immunogenicity of the N, P, M, NV and $G$ proteins of infectious hematopoietic necrosis virus in rainbow trout oncorhynchus mykiss using DNA vaccines. Dis Aquat Organ. (1999) 39:2936. doi: 10.3354/dao039029

208. Traxler GS, Anderson E, LaPatra SE, Richard J, Shewmaker B, Kurath G. Naked DNA vaccination of Atlantic salmon Salmo salar against IHNDis, V. Aquat Organ. (1999) 38:183-90. doi: 10.3354/dao038183

209. Corbeil S, LaPatra SE, Anderson ED, Kurath G. Nanogram quantities of a DNA vaccine protect rainbow trout fry against heterologous strains of infectious hematopoietic necrosis virus. Vaccine. (2000) 18:281724. doi: $10.1016 / \mathrm{S} 0264-410 \mathrm{X}(00) 00078-5$

210. Lorenzen N, Lorenzen E, Einer-Jensen K, LaPatra SE. Immunity induced shortly after DNA vaccination of rainbow trout against rhabdoviruses protects against heterologous virus but not against bacterial pathogens. Dev Comp Immunol. (2002) 26:173-9. doi: 10.1016/S0145-305X(01)00059-3

211. Garver KA, LaPatra SE, Kurath G. Efficacy of an infectious hematopoietic necrosis (IHN) virus DNA vaccine in Chinook Oncorhynchus tshawytscha and sockeye nerka, O. salmon. Dis Aquat Organ. (2005) 64:13-22. doi: 10.3354/dao064013

212. Purcell MK, Nichols KM, Winton JR, Kurath G, Thorgaard GH, Wheeler P, et al. Comprehensive gene expression profiling following DNA vaccination of rainbow trout against infectious hematopoietic necrosis virus. Mol Immunol. (2006) 43:2089-106. doi: 10.1016/j.molimm.2005.12.005

213. Holvold LB, Myhr AI, Dalmo RA. Strategies and hurdles using DNA vaccines to fish. Vet Res. (2014) 45:21. doi: 10.1186/1297-9716-45-21

214. Long A, Richard J, Hawley L, LaPatra SE, Garver KA. Transmission potential of infectious hematopoietic necrosis virus in APEXIHN(R)-vaccinated Atlantic salmon. Dis Aquat Organ. (2017) 122:213-21. doi: 10.3354/dao03076

215. Jansen M, Bang B, Jensen McLoughlin M, Rodger H, Taksdal T, Sindre $\mathrm{H}$, et al. The epidemiology of pancreas disease in salmonid aquaculture: a summary of the current state of knowledge. J Fish Dis. (2016) 40:12478. doi: $10.1111 / \mathrm{jfd} .12478$

216. Thorarinsson R, Wolf JC, Inami M, Phillips L, Jones G, Macdonald AM, et al. Effect of a novel DNA vaccine against pancreas disease caused by salmonid alphavirus subtype 3 in Atlantic salmon (Salmo salar). Fish Shellfish Immunol. (2021) 108:116-26. doi: 10.1016/j.fsi.2020.12.002

217. European Food Safety A, Houston R, Moxon S, Nogué Papadopoulou F, Ramon N, Waigmann M, et al. Assessment of the potential integration of the DNA plasmid vaccine CLYNAV into the salmon genome. EFSA J. (2017) 15:e04689. doi: 10.2903/j.efsa.2017.4689

218. Brett Petersen W, Ryan Wallace M, Jesse Blanton D. Rabies surveillance in the United States during 2017. J Am Vet Medical Assoc. (2018) 253:155568. doi: 10.2460/javma.253.12.1555

219. Maki J, Guiot AL, Aubert M, Brochier B, Cliquet F, Hanlon CA, et al. Oral vaccination of wildlife using a vaccinia-rabies-glycoprotein recombinant virus vaccine (RABORAL V-RG((R))): a global review. Vet Res. (2017) 48:57. doi: 10.1186/s13567-017-0459-9

220. Blancou J, Kieny MP, Lathe R, Lecocq JP, Pastoret PP, Soulebot JP, et al. Oral vaccination of the fox against rabies using a live recombinant vaccinia virus. Nature. (1986) 322:373-5. doi: 10.1038/322373a0

221. Tolson ND, Charlton KM, Casey GA, Knowles MK, Rupprecht CE, Lawson KF, et al. Immunization of foxes against rabies with a vaccinia recombinant virus expressing the rabies glycoprotein. Arch Virol. (1988) 102:297-301. doi: 10.1007/BF01310835
222. Sidwa TJ, Wilson PJ, Moore GM, Oertli EH, Hicks BN, Rohde RE, et al. Evaluation of oral rabies vaccination programs for control of rabies epizootics in coyotes and gray foxes, 1995-2003. J Am Vet Med Assoc. (2005) 227:785-92. doi: 10.2460/javma.2005.227.785

223. Rupprecht CE, Wiktor TJ, Johnston DH, Hamir AN, Dietzschold B, Wunner $\mathrm{WH}$, et al. Oral immunization and protection of raccoons (Procyon lotor) with a vaccinia-rabies glycoprotein recombinant virus vaccine. Proc Natl Acad Sci USA. (1986) 83:7947-50. doi: 10.1073/pnas.83.20.7947

224. Hanlon CA, Niezgoda M, Hamir AN, Schumacher C, Koprowski H, Rupprecht CE. First North American field release of a vacciniarabies glycoprotein recombinant virus. J Wildl Dis. (1998) 34:22839. doi: $10.7589 / 0090-3558-34.2 .228$

225. Brown LJ, Rosatte RC, Fehlner-Gardiner C, Knowles MK, Bachmann $\mathrm{P}$, Davies JC, et al. Immunogenicity and efficacy of two rabies vaccines in wild-caught, captive raccoons. J Wildl Dis. (2011) 47:182-94. doi: 10.7589/0090-3558-47.1.182

226. Brown LJ, Rosatte RC, Fehlner-Gardiner C, Taylor JS, Davies JC, Donovan D. Immune response and protection in raccoons (Procyon lotor) following consumption of baits containing $\operatorname{ONRAB}(\mathrm{R})$, a human adenovirus rabies glycoprotein recombinant vaccine. J Wildl Dis. (2012) 48:101020. doi: 10.7589/2012-01-023

227. Fehlner-Gardiner C, Rudd R, Donovan D, Slate D, Kempf L, Badcock J. Comparing ONRAB(R) AND RABORAL V-RG(R) oral rabies vaccine field performance in raccoons and striped skunks, New Brunswick, Canada, and Maine, USJ, A. Wildl Dis. (2012) 48:157-67. doi: 10.7589/0090-3558-48.1.157

228. Calvete C. Modeling the effect of population dynamics on the impact of rabbit hemorrhagic disease. Conserv Biol. (2006) 20:1232-41. doi: 10.1111/j.1523-1739.2006.00371.x

229. Best SM, Collins SV, Kerr PJ. Coevolution of host and virus: cellular localization of virus in myxoma virus infection of resistant and susceptible European rabbits. Virology. (2000) 277:76-91. doi: 10.1006/viro.2000.0505

230. Division VM. CVMP Assessment report for Nobivac Myxo-RHD plus (EMEA/V/C/004989/0000). Amsterdam: Committee for Medicinal Products for Veterinary Use E. M. Agency (2019).

231. Spibey N, McCabe VJ, Greenwood NM, Jack SC, Sutton D, van der Waart L. Novel bivalent vectored vaccine for control of myxomatosis and rabbit haemorrhagic disease. Vet Rec. (2012) 170:309. doi: 10.1136/vr.100366

232. Pollard AJ, Launay O, Lelievre JD, Lacabaratz C, Grande S, Goldstein $\mathrm{N}$, et al. Safety and immunogenicity of a two-dose heterologous Ad26.ZEBOV and MVA-BN-Filo Ebola vaccine regimen in adults in Europe (EBOVAC2): a randomised, observer-blind, participant-blind, placebo-controlled, phase 2 trial. Lancet Infect Dis. (2020) 21:493-506. doi: 10.1016/S1473-3099(20)30476-X

233. Polack FP, Thomas SJ, Kitchin N, Absalon J, Gurtman A, Lockhart S, et al. Safety and efficacy of the BNT162b2 mRNA covid-19 vaccine. N Engl J Med. (2020) 383:2603-15. doi: 10.1056/NEJMoa2034577

234. Baden LR, El Sahly HM, Essink B, Kotloff K, Frey S, Novak R, et al. Efficacy and safety of the mRNA-1273 SARS-CoV-2 vaccine. N Engl J Med. (2020) 384:403-16. doi: 10.1056/NEJMoa2035389

235. Voysey M, Clemens SAC, Madhi SA, Weckx LY, Folegatti PM, Aley PK, et al. Safety and efficacy of the ChAdOx1 nCoV-19 vaccine (AZD1222) against SARS-CoV-2: an interim analysis of four randomised controlled trials in Brazil, South Africa, and the UK. Lancet. (2021) 397:99-111. doi: 10.1016/S0140-6736(20)32661-1

236. Noad R, Roy P. Virus-like particles as immunogens. Trends Microbiol. (2003) 11:438-44. doi: 10.1016/S0966-842X(03)00208-7

237. Brisse M, Vrba SM, Kirk N, Liang Y, Ly H. Emerging concepts and technologies in vaccine development. Front Immunol. (2020) 11:583077. doi: 10.3389/fimmu.2020.58 3077

238. Mohsen MO, Zha L, Cabral-Miranda G, Bachmann MF. Major findings and recent advances in virus-like particle (VLP)-based vaccines. Semin Immunol. (2017) 34:123-32. doi: 10.1016/j.smim.2017.08.014

239. Lugade AA, Bharali DJ, Pradhan V, Elkin G, Mousa SA, Thanavala Y. Single low-dose un-adjuvanted HBsAg nanoparticle vaccine elicits robust, durable immunity. Nanomedicine. (2013) 9:923-34. doi: 10.1016/j.nano.2013. 03.008 
240. Diaz-Arévalo D, Zeng M. Nanoparticle-based vaccines: opportunities and limitations. Nanopharmaceuticals. (2020) 135-50. doi: 10.1016/B978-0-12-817778-5.00007-5

241. Buschmann MD, Carrasco MJ, Alishetty S, Paige M, Alameh MG, Weissman D. Nanomaterial delivery systems for mRNA vaccines. Vaccines. (2021) 9:10065. doi: 10.3390/vaccines 9010065

242. Miquel-Clopés A, Bentley EG, Stewart JP, Carding SR. Mucosal vaccines and technology. Clin Exp Immunol. (2019) 196:205-14. doi: 10.1111/cei.13285

243. Jain AK, Goyal AK, Mishra N, Vaidya B, Mangal S, Vyas SP. PEG-PLA-PEG block copolymeric nanoparticles for oral immunization against hepatitis B. Int J Pharm. (2010) 387:253-62. doi: 10.1016/j.ijpharm.2009.12.013

244. Doavi T, Mousavi SL, Kamali M, Amani J, Fasihi Ramandi M. Chitosanbased intranasal vaccine against Escherichia coli O157:H7. Iran Biomed J. (2016) 20:97-108. doi: 10.7508/ibj.2016.02.005

245. $\mathrm{Hu} \mathrm{KF}$, Lövgren-Bengtsson K, Morein B. Immunostimulating complexes (ISCOMs) for nasal vaccination. Adv Drug Delivery Rev. (2001) 51:14959. doi: 10.1016/S0169-409X(01)00165-X

246. Sanina N, Chopenko N, Mazeika A, Kostetsky E. Nanoparticulate tubular immunostimulating complexes: novel formulation of effective adjuvants and antigen delivery systems. BioMed Res Int. (2017) 2017:4389525. doi: 10.1155/2017/4389525

247. Paillot R. A systematic review of recent advances in equine influenza vaccination. Vaccines. (2014) 2:797-831. doi: 10.3390/vaccines2040797

248. Paillot R, Fraser S, Prowse-Davis L, Rash N, Montesso F, Slootmans $\mathrm{N}$, et al. ISCOM-based equine influenza vaccine: duration of immunity and randomised clinical trials to assess an accelerated schedule of immunisation and efficacy. Trials Vaccinol. (2015) 4:61-70. doi: 10.1016/j.trivac.2015.07.002

249. Li L, Petrovsky N. Molecular adjuvants for DNA vaccines. Curr Issues Mol Biol. (2017) 22:17-40. doi: 10.21775/cimb.022.017

250. Suschak JJ, Williams JA, Schmaljohn CS. Advancements in DNA vaccine vectors, non-mechanical delivery methods, and molecular adjuvants to increase immunogenicity. Hum Vaccines Immunotherapeut. (2017) 13:283748. doi: 10.1080/21645515.2017.1330236

251. Sabbaghi A, Ghaemi A. Molecular adjuvants for DNA vaccines: application, design, preparation, and formulation. Methods Mol Biol. (2021) 2197:87112. doi: 10.1007/978-1-0716-0872-2_5

252. Somani J, Lonial S, Rosenthal H, Resnick S, Kakhniashvili I, Waller EK. A randomized, placebo-controlled trial of subcutaneous administration of GM-CSF as a vaccine adjuvant: effect on cellular and humoral immune responses. Vaccine. (2002) 21:221-30. doi: 10.1016/S0264-410X(02)00463-2

253. Ben-Yehuda A, Joseph A, Barenholz Y, Zeira E, Even-Chen S, LouriaHayon I, et al. Immunogenicity and safety of a novel IL-2-supplemented liposomal influenza vaccine (INFLUSOME-VAC) in nursing-home residents. Vaccine. (2003) 21:3169-78. doi: 10.1016/S0264-410X(03)00 251-2

254. Hu H, Tao L, Wang Y, Chen L, Yang J, Wang H. Enhancing immune responses against SARS-CoV nucleocapsid DNA vaccine by co-inoculating interleukin-2 expressing vector in mice. Biotechnol Lett. (2009) 31:168593. doi: 10.1007/s10529-009-0061-y

255. Chen Y, Wang S, Lu S. DNA immunization for HIV vaccine development. Vaccines. (2014) 2:138-59. doi: 10.3390/vaccines2010138

Conflict of Interest: The authors declare that the research was conducted in the absence of any commercial or financial relationships that could be construed as a potential conflict of interest.

Copyright (c) 2021 Aida, Pliasas, Neasham, North, McWhorter, Glover and Kyriakis. This is an open-access article distributed under the terms of the Creative Commons Attribution License (CC BY). The use, distribution or reproduction in other forums is permitted, provided the original author(s) and the copyright owner(s) are credited and that the original publication in this journal is cited, in accordance with accepted academic practice. No use, distribution or reproduction is permitted which does not comply with these terms. 